\title{
Naar een informatiesysteem onderwijs-arbeidsmarkt voor de haven van Rotterdam : verslag vooronderzoek
}

Citation for published version (APA):

de Grip, A., Heijke, J. A. M., Nusselder, W. J., \& Ramaekers, G. W. M. (1989). Naar een

informatiesysteem onderwijs-arbeidsmarkt voor de haven van Rotterdam : verslag vooronderzoek. Researchcentrum voor Onderwijs en Arbeidsmarkt, Faculteit der Economische Wetenschappen. ROA Reports No. 2 https://doi.org/10.26481/umarep.1989002

Document status and date:

Published: 01/01/1989

DOI:

10.26481/umarep.1989002

Document Version:

Publisher's PDF, also known as Version of record

\section{Please check the document version of this publication:}

- A submitted manuscript is the version of the article upon submission and before peer-review. There can be important differences between the submitted version and the official published version of record.

People interested in the research are advised to contact the author for the final version of the publication, or visit the DOI to the publisher's website.

- The final author version and the galley proof are versions of the publication after peer review.

- The final published version features the final layout of the paper including the volume, issue and page numbers.

Link to publication

\footnotetext{
General rights rights.

- You may freely distribute the URL identifying the publication in the public portal. please follow below link for the End User Agreement:

www.umlib.nl/taverne-license

Take down policy

If you believe that this document breaches copyright please contact us at:

repository@maastrichtuniversity.nl

providing details and we will investigate your claim.
}

Copyright and moral rights for the publications made accessible in the public portal are retained by the authors and/or other copyright owners and it is a condition of accessing publications that users recognise and abide by the legal requirements associated with these

- Users may download and print one copy of any publication from the public portal for the purpose of private study or research.

- You may not further distribute the material or use it for any profit-making activity or commercial gain

If the publication is distributed under the terms of Article $25 \mathrm{fa}$ of the Dutch Copyright Act, indicated by the "Taverne" license above, 
Naar een informatiesysteem

onderwijs-arbeidsmarkt voor de haven van Rotterdam

- Verslag Vooronderzoek -

ROA-R-!989/2 
NAAR EEN INFORMATIESYSTEEM ONDERWIJS-ARBEIDSMARKT YOOR DE HAVEN VAN ROTTERDAM

- verslag vooronderzoek -

ROA-R-1989/2

A. de Grip, J.A.M. Heijke, W.J. Nusselder, G.W.M. Ramaekers

RESEARCHCENTRUM VOOR' ONDERWIJS EN ARBEIDSMARKT

Faculteit der Economische Wetenschappen

Rijksuniversiteit Limburg

Maastricht, augustus 1989 
INHOUDSOPGAVE

Bladzijde

VERANTWOORDING

SAMENVATTING

1. INLEIDING

2. DE OPZET VAN HET INFORMATIESYSTEEM

2.1. Inleiding

2.2. Doelgroepen en gebruikerswensen

2.3. Uitgangspunten

2.4. De variabelen

3. HET INFORMATIESYSTEEM ONDERWIJS-ARBEIDSMARKT IN SCHEMA 8

3.1. Inleiding

3.2. Vraag en aanbod

3.3. Discrepanties

4. GRENZEN EN CLASSIFICATIES 14

4.1. De grenzen van het informatiesysteem 14

4.2. De ruimtelijke afbakening 14

4.3. De bedrijuen 15

4.4. De functies 18

4.5. De opleidingen 21

4.6. De werklozen 23

5. EVALUATIE VAN DE BENODIGDE GEGEVENS 25

5.1. Inleiding 25

5.2. Werkgelegenheidsgegevens 25

5.3. Onderwijsgegevens 28

5.4. Werkloosheidsgegevens 30

6. NAAR EEN INFORMATIESYSTEEM 31

6.1. Inleiding 31

6.2. Informatie met betrekking tot bedrijuen 31

6.2.1. Het monitoringsysteem 31

6.2.2. Het prognosesysteem 33 
6.4. Informatie over opleidingen 36

6.4.1. Het monitoringsysteem 36

6.4.2. Het prognosesysteem 36

7. OPZET EN FASERING VAN HET ONDERZOEK 38

7.1. Voorgestelde werkwijze 38

7.2. De onderdelen van het informatiesysteem 39

7.3. Ontwikkelingsfasen van het informatiesysteem 43

7.4. Enkele organisatorische aspecten 47

$\begin{array}{ll}\text { LITERATUURLIJST } & 49\end{array}$

BIJLAGE 1: Lijst van geïnterviewde personen 51

BIJLAGE 2: Het goederenstromenmodel 52

BIJLAGE 3: Ruimtelijke afbakening van het informatiesysteem 53

BIJLAGE 4: Overzicht van de HB-sector-indeling 55

BIJLAGE 5: Vertaling van HB-sector-code naar SBI-code 57

BIJLAGE 6: Aantal vestigingen, aantal werknemers en

gemiddelde vestigingsgrootte per HB-sub-sector

per 1-5-' 87

BIJLAGE 7: Overzicht van beroepen/functie-indelingen 59

BIJLAGE 8: Functie-indeling personeelregistratiesysteem SVZ en de relatie tussen SVZ-code en CBS-code 63

BIJLAGE 9: Lijst van telefonisch benaderde opleidingsinstituten 65

BIJLAGE 10: Cursussen HVS "Dr。A.J.T. Stakenburg" 66

BIJLAGE 11: Overzicht van het onderwijsaanbod 67

BIJLAGE 12: Overzicht van de relevante beroepen van de ARBIindeling $\quad 69$

BIJLAGE 13: Registraties van werkgelegenheidsgegevens 71

BIJLAGE 14: Formulier aanmelding en mutatie personeel SVZ 73

BIJLAGE 15: Enquêteformulier RUBS 74

- Vragenlijst voor schoolverlaters LBO en MAVO $1987 / 88$

- Vragenlijst voor schoolverlaters MBO, KMBO, HAVO/VWO en HBO 1987/88 78

BIJLAGE 16: Vraagformulier project Metaal-electro ZuidwestNederland 


\section{VERANTWOORDING}

Dit rapport vormt het verslag van een vooronderzoek naar de mogelijkheden voor het ontwikkelen van een systeem dat bruikbare informatie oplevert over de actuele en de toekomstige ontwikkelingen op de arbeidsmarkt in relatie tot die in het onderwijs in de Rotterdamse haven. Het vooronderzoek is uitgevoerd in opdracht van het Gemeentelijk Havenbedrijf Rotterdam.

Het onderzoek werd onder leiding van prof. dr. J.A.M. Heijke en dr. A. de Grip uitgevoerd door drs. W.J. Nusselder en drs. G.W.M. Ramaekers. M.A. Mortier en J.J. Smorenburg verleenden assistentie bij dit onderzoek.

De onderzoekers werden begeleid door een speciaal voor dit doel samengestelde commissie, bestaande uit vertegenwoordigers van sociale partners, onderwijsinstellingen, de Kamer van Koophandel en Fabrieken voor Rotterdam en de Beneden-Maas, het Gewestelijk Arbeidsbureau Rotterdam en het Gemeentelijk Havenbedrijf Rotterdam. De samenstelling van deze commissie is weergegeven in bijlage 1 .

Zonder de bijdrage van de leden van de begeleidingscommissie en andere gesprekspartners die bereid waren ons te woord te staan, was het onmogelijk geweest dit vooronderzoek uit te voeren. 
SAMENVATTING

In dit verslag van een uitgevoerd vooronderzoek wordt een voorstel gepresenteerd voor het opzetten van een informatiesysteem onderwijsarbeidsmarkt voor de haven van Rotterdam. Gestreefd wordt naar een gebruiksvriendelijk informatiesysteem dat beleidsrelevante informatie kan verschaffen over de actuele en de op middellange termijn te verwachten situatie op de arbeidsmarkt en in het onderwijs, met name met betrekking tot de kwantitatieve en de kwalitatieve discrepanties. Hierbij zal niet alleen aandacht worden besteed aan de omvang van de vraag naar en het aanbod van arbeidskrachten per bedrijfssector, maar zal tevens onderscheid worden gemakt naar de functie-kwalificaties en de vooropleiding.

Het informatiesysteem onderwijs-arbeidsmarkt kan worden opgebouwd uit een monitoringsysteem dat jaarlijks actuele gegevens oplevert over de ontwikkelingen op de arbeidsmarkt en in het onderwijs, een prognosesysteem dat tweejaarlijks bijgestelde prognoses oplevert van de vervangingsvraag, de uitbreidingsvraag en de uitstroom uit het onderwijs en tenslotte een systeem waarmee (toekomstige) veranderingen in kwalificatieprofielen van een elk jaar wisselende fractie van de functies in beeld kunnen worden gebracht.

Van een dergelijk informatiesysteem kunnen diverse doelgroepen profiteren. Zo kan het systeem voor de bedrijven essentiële informatie opleveren over de (dreigende) kwantitatieve en kwalitatieve discrepanties in de samenstelling van het personeelsbestand en ook over de mate waarin de uitstroom uit het reguliere en het bijscholingsonderwijs deze discrepanties kan overbruggen. Voor de scholen kan het informatiesysteem inzicht verschaffen in de vraag naar opgeleiden en de kwalificatie-eisen die aan afgestudeerden worden gesteld. Dergelijke informatie is onder meer van belang voor het samenstellen van onderwijsprogramma's en de planning van de capaciteit van onderwijsvoorzieningen. Daarnaast kunnen ook andere instellingen zoals het Gewestelijk Arbeidsbureau, de Kamer van Koophandel en Fabrieken, de vakbonden en het Gemeentelijk Havenbedrijf Rotterdam van het informatiesysteem profiteren bij hun beleidsbepaling.

Het informatiesysteem zal betrekking hebben op de werkgelegenheid van bedrijven die zijn gevestigd in het gebied van het voormalig Openbaar Lichaam Rijnmond en die activiteiten verrichten die zijn gericht op de open overslag van goederen en de administratieve verwerking die dit proces met 
zich mee brengt. Daarnaast zal de uitstroom uit een aantal opleidingsinstituten die opleidingen of cursussen verzorgen die gericht zijn op het uitoefenen van een functie in de haven, en het potentiële aanbod van werklozen worden opgenomen in het informatiesysteem. Voorgesteld wordt om de gegevens in het informatiesysteem die betrekking hebben op functies waarvoor havengerichte opleidingen worden aangeboden naar behoefte te detailleren en de overige functies meer globaal te beschouwen. De nader te detailleren functies hebben met name betrekking op de operationele en de (technisch) administratieve activiteiten. Zij zullen worden samengevoegd tot categorieën die grotendeels aansluiten bij de functies die in het personeelregistratiesysteem van de SVZ en in de CAO's worden gehanteerd.

Bij het opzetten van het informatiesysteem zal zoveel mogelijk gebruik worden gemaakt van bestaande gegevensbestanden, teneinde de overlast voor de bedrijuen, de scholen en andere instellingen tot het minimum te beperken. Het personeelregistratiesysteem van de SVZ zal de belangrijkste gegevens leveren over de werkgelegenheid in de haven. Informatie over bedrijven die niet onder het personeelregistratiesysteem vallen en/of gegevens die niet aan dit registratiesysteem kunnen worden ontleend, zullen additioneel worden verzameld middels enquêtes en mogelijk ook door middel van gesprekken met sleutelfiguren. De onderwijsgegevens zullen deels door de scholen zelf moeten worden verstrekt en deels door het houden van een schoolverlatersenquête moeten worden verzameld. Gegevens over het potentiële aanbod van werklozen zullen door het Gewestelijk Arbeidsbureau moeten worden geleverd.

Voorgesteld wordt om het informatiesysteem in eerste instantie te ontwikkelen voor alleen de bedrijven die zijn opgenomen in het personeelregistratiesysteem van de SVZ. Vervolgens zullen meer havenactiviteiten worden toegevoegd tot uiteindelijk een compleet beeld van de haven van Rotterdam en het onderwijs kan worden verschaft. Deze benadering resulteert in een drietal ontwikkelingsfasen.

In de eerste fase zal het personeelregistratiesysteem van de SVZ verder worden uitgebouwd en zullen historische gegevens worden verzameld over de werkgelegenheid en het onderwijs. Daarnaast zullen de bedrijven die buiten dit systeem vallen worden geïnventariseerd en zal een schoolverlatersenquête worden opgezet. Tenslotte zal in deze fase een meetinstrument worden ontwikkeld om profielen van functies en de daaraan gekoppelde kwalificatieeisen te bepalen. 
In de tweede fase zal een enquête, over enkele kenmerken die niet in het personeelregistratiesysteem worden bijgehouden, worden ontwikkeld en afgenomen onder bedrijven die lid zijn van de SVZ. Tevens zullen in deze fase extrapolatietechnieken worden ontwikkeld voor het maken van middellange termijnprognoses. De prognoses zullen eventueel worden bijgesteld na toetsing aan de opinies van sleutelfiguren. Ook zal het instrument voor het meten van kwalificatieprofielen worden toegepast op een beperkt aantal functies.

In de derde ontwikkelingsfase zullen de tot dusver ontwikkelde technieken worden bijgesteld en kunnen bedrijven die niet onder het personeelregistratiesysteem van de SVZ vallen aan het systeem worden toegevoegd. Deze fase zal worden afgesloten met het opstellen van een draaiboek met het ontwikkelen van een meetinstrument voor de technologische ontwikkelingen op middellange termijn en hun implicaties voor de omvang, de functiestructuur en het kwalificatieprofiel van de werkgelegenheid.

Voor het welslagen van dit project is het van cruciaal belang dat medewerking wordt verkregen van de betrokken bedrijven, het netwerk van sleutelpersonen, de SVZ, het COA-Rijndelta, het GAB, de betrokken scholen en van het Havenbedrijf Rotterdam. Het systeem zal mede hierom moeten worden beheerd door een in de regio gevestigde onafhankelijke instelling die over de nodige expertise beschikt en het vertrouwen geniet van alle betrokkenen. 


\section{INLEIDING}

In dit rapport worden de resultaten beschreven van een vooronderzoek naar de mogelijkheden voor het opzetten van een informatiesysteem onderwijs-arbeidsmarkt ten behoeve van de haven van Rotterdam. Het doel van het vooronderzoek was het schetsen van de mogelijke opzet van een informatiesysteem waarmee de (toekomstige) ontwikkelingen in de omvang en de samenstelling van de werkgelegenheid in de haven van Rotterdam kunnen worden weergegeven en dat een confrontatie mogelijk makt van deze ontwikkelingen met de (verwachte) uitstroom van leerlingen uit de verschillende havenopleidingen.

Het vooronderzoek omvatte een literatuurstudie van vergelijkbare onderzoekingen in andere sectoren en een aantal gesprekken met deskundigen binnen en buiten de haven. Daarnaast is een inventarisatie gemaakt van de voor de haven relevante bedrijfssectoren, beroepen en opleidingen. Bovendien is de eventuele bruikbaarheid van aanwezige databronnen voor het op te zetten informatiesysteem onderzocht.

De verslaglegging van de resultaten van het vooronderzoek is als volgt opgezet. In hoofdstuk 2 worden de doelgroepen, gebruikerswensen en de uitgangspunten van het informatiesysteem beschreven. Vervolgens wordt in hoofdstuk 3 het te ontwikkelen informatiesysteem geschetst in de vorm van een schema. In dit schema worden de elementen waaruit het informatiesysteem wordt opgebouwd benoemd en in een onderling verband geplaatst. De grenzen van het informatiesysteem en de te hanteren classificaties komen in hoofdstuk 4 aan bod. In hoofdstuk 5 wordt ingegaan op de gegevens die nodig zijn om de elementen van het informatiesysteem te kunnen meten en op de gegevens die vooralsnog ontbreken gezien de beperkingen van de bestaande databronnen. In hoofdstuk 6 wordt voorgesteld op welke wijze de ontbrekende gegevens systematisch verzameld en geregistreerd kunnen worden als aanvulling op de reeds bestaande registraties. Tenslotte wordt in hoofdstuk 7 een gefaseerde aanpak voor de ontwikkeling van het beoogde informatiesysteem gepresenteerd. 


\section{DE OPZET VAN HET INFORMATIESYSTEEM}

\subsection{Inleiding}

Bedrijuen en instellingen, die actief zijn in het Rotterdamse havengebied, hebben ter ondersteuning van hun beleid behoefte aan makkelijk toegankelijke informatie over de ontwikkelingen op de arbeidsmarkt in relatie tot die in het onderwijs. Een informatiesysteem dat inzicht verschaft in de actuele en de toekomstige situatie op de arbeidsmarkt en in het onderwijs, voorziet in een dringende behoefte. Teneinde een adequat werkgelegenheids- en scholingsbeleid te kunnen voeren is het voor de betrokken bedrijven en instanties van belang te anticiperen op de toekomstige ontwikkelingen in de omvang en de samenstelling van de werkgelegenheid naar functies en in de opleidingseisen die zullen worden gesteld. Het anticiperen op toekomstige ontwikkelingen gaat echter gepaard met onzekerheid. Een informatiesysteem dat inzicht verschaft in enerzijds de actuele, alsmede de op middellange termijn te verwachten, kwantitatieve en kwalitatieve discrepanties tussen de vraag naar arbeidskrachten voor de verschillende functies en anderzijds het aanbod van arbeidskrachten dat over de vereiste onderwijskwalificaties beschikt om deze functies te vervullen, kan deze onzekerheid doen verminderen.

In dit hoofdstuk zullen achtereenvolgens de gesprekken met de verschillende potentiële gebruikers over de toepassingsgebieden en hun verwachtingen ten aanzien van het informatiesysteem onderwijs-arbeidsmarkt worden geëvalueerd. Vervolgens zullen op basis hiervan een aantal uitgangspunten voor het systeem worden geformuleerd. Tenslotte zal worden aangegeven welke concrete informatie het systeem zal moeten opleveren, wil het aan de verwachtingen van de potentiële gebruikers kunnen voldoen.

\subsection{Doelgroepen en gebruikerswensen}

Van een systeem onderwijs-arbeidsmarkt dat informatie geeft over de ontwikkeling van de omvang en de samenstelling van de werkgelegenheid in de haven van Rotterdam, alsmede over de relatie tussen de ontwikkeling van de werkgelegenheid en de uitstroom uit de verschillende op havenfuncties gerichte vakopleidingen, kunnen diverse doelgroepen gebruik maken.

Allereerst kan het onderwijs profiteren van een dergelijk informatiesysteem. De havengerichte scholen zijn gebaat bij een informatiesysteem met het oog 
op hun onderwijsplanning, de werving van leerlingen en de samenstelling van de onderwijsprogramma's. Daarnaast kunnen ook scholieren en schooldecanen hun voordeel doen met informatie over de arbeidsmarktperspectieven van opleidingen in verband met de studie- en beroepskeuze(advisering). De Scheepvaart Vereniging Zuid (SVZ) is als werkgeversvereniging mede-financier van de opleidingen van de Stichting Vervoer- en Havenopleidingen (SVH) en heeft als zodanig ook belang bij de afstemming van de omvang, samenstelling en inhoud van het scholingsaanbod op de vraag naar afgestudeerden met een bepaalde opleiding.

De bedrijven vormen een volgende gebruikersgroep. De bedrijven in het Rotterdamse havengebied zijn gebaat bij arbeidsmarktinformatie ter onderbouwing van hun personeelsbeleid, met name voor wat betreft het wervingsbeleid en de om-, her- en bijscholingsplannen met betrekking tot het aanwezige personeel.

Het systeem kan ook voor het Gewestelijk Arbeidsbureau (GAB) en de vakbonden waardevolle informatie opleveren. Het Gewestelijk Arbeidsbureau kan bij de formulering van om-, her- en bijscholingsplannen voor werklozen van het informatiesysteem gebruik maken, met betrekking tot zowel de aard van de scholing als de gewenste opleidingscapaciteit. Voor de vakbonden kan het systeem na verloop van tijd gegevens opleveren over de benutting van het kwalificatiepotentieel van de reeds werkzame beroepsbevolking en van de toestroom van jongeren naar de arbeidsmarkt. Daarnaast kan het systeem ook dienen ter ondersteuning van het beleid van het nog op te richten Regionale Bestuur voor de Arbeidsvoorziening (RBA) (waarin ook de vakbonden vertegenwoordigd zullen zijn) met name ten bate van het toewijzingsbeleid van gelden voor scholingsdoeleinden.

Het Gemeentelijk Havenbedrijf Rotterdam (GHB) tenslotte, streeft als opdrachtgever van dit onderzoek naar de ontwikkeling van een informatiesysteem onderwijs-arbeidsmarkt dat kan fungeren als een infrastructurele voorziening, waarvan naast het havenbedrijf zelf, ook de bovengenoemde doelgroepen bij hun beleidsbepaling in ruime mate kunnen profiteren.

De leden van de begeleidingscommissie hebben in individuele gesprekken met de onderzoekers een aantal gebruikerswensen geformuleerd. De verwachtingen ten aanzien van het op te zetten informatiesysteem vertonen onderling grote overeenkomsten. Kort samengevat zal het informatiesysteem onderwijs-arbeids- 
markt periodiek informatie moeten verschaffen over de recente ontwikkelingen op de arbeidsmarkt in de Rotterdamse haven. Daarnaast moeten met behulp van het systeem ook prognoses kunnen worden gemaakt van de toekomstige ontwikkelingen.

Over de wenselijk of realiseerbaar geachte prognosetermijn liepen de meningen enigszins uiteen. Enkele gesprekspartners makten een keuze kenbaar voor korte-termijnprognoses. Anderen achtten middellange-termijnprognoses wenselijk, doch niet op korte termijn realiseerbaar. Uit zowel de gesprekken als uit de relevante literatuur blijkt dat ondernemers in de Rotterdamse haven met betrekking tot hun personeelsbeleid 2 à 3 jaar vooruit kunnen plannen (Bochhove en Van Eyck, 1989). Vooralsnog wordt verwacht dat prognoses van de ontwikkelingen op de arbeidsmarkt voor een langere periode, bijvoorbeeld vijf jaar, dan ook slechts een globaal karakter kunnen hebben. Naar de mening van het merendeel van de gesprekspartners zouden gedetailleerde prognoses voor de middellange-termijn uiteindelijk wel mogelijk zijn.

Een deel van de gesprekspartners gaf prioriteit aan het verschaffen van informatie over (dreigende) kwantitatieve discrepanties op de arbeidsmarkt. Anderen daarentegen waren meer geïnteresseerd in informatie met betrekking tot mogelijke kwalitatieve discrepanties. Zo spraken enkele leden van de begeleidingscommissie een duidelijke voorkeur uit voor het verschaffen van meer informatie over (de ontwikkeling van) de functiekwalificaties en over de gevolgen hiervan voor de te stellen opleidingseisen. Het merendeel van de gesprekspartners benadrukte echter het grote belang van de beschikbaarheid van informatie over de ontwikkeling van de omvang en samenstelling van de vraag en het aanbod op de arbeidsmarkt.

\subsection{Uitgangspunten}

Op grond van de wensen en verwachtingen van gebruikers ten aanzien van het te ontwikkelen informatiesysteem onderwijs-arbeidsmarkt zoals deze in de vorige paragraaf zijn uiteengezet, kunnen enkele uitgangspunten voor het informatiesysteem worden geformuleerd. Hierbij dient men in het oog te houden dat met het informatiesysteem twee doelstellingen worden nagestreefd. Ten eerste het "monitoren" van de actuele situatie op de arbeidsmarkt in relatie tot die in het onderwijs en op de tweede plaats het maken van prognoses. De uitgangspunten zijn: 
a. Het informatiesysteem zal representatieve informatie moeten opleveren over de (dreigende) tekorten en overschotten aan arbeidskrachten in de verschillende sectoren van de Rotterdamse haven. Tevens zal het systeem (dreigende) discrepanties tussen de voor de verschillende functies vereiste kennis en vaardigheden enerzijds en de kennis en vaardigheden van het reeds aanwezige personeel en de (her)intreders op de arbeidsmarkt anderzijds aan het licht moeten brengen.

b. Het informatiesysteem zal in elk geval een consistent overzicht moeten geven van de werkgelegenheid (naar sector, functie en opleiding), het personeelsverloop (naar sector, functie en opleiding), de uitstroom van de opleidingen (naar type opleiding, niveau en afstudeerrichting), de bestemming van deze uitstroom (naar sector en functie) en de mobiliteit van het personeel tussen de bedrijven en de sectoren in de Rotterdamse haven, van en naar de sectoren buiten de Rotterdamse haven, van en naar de werkloosheid en van en naar de overige beroepsbevolking op een zo recent mogelijk tijdstip.

c. De prognoses zullen gegevens moeten opleveren over de ontwikkelingen in de omvang en samenstelling van zowel de vraag (werkgelegenheidsontwikkeling en vervangingsbehoefte) als het aanbod op de arbeidsmarkt. Voor het bepalen van de behoefte aan om-, her- en bijscholing is het noodzakelijk dat het systeem tevens informatie oplevert over de dreigende kwalitatieve discrepanties tussen de vraag en het aanbod op de arbeidsmarkt. Voor het afstemmen van het reguliere onderwijsaanbod op de vraag naar werknemers met een bepaalde opleiding, is een prognosetermijn van 4 à 5 jaar wenselijk. Voor de duidelijkheid dient hierbij te worden opgemerkt dat niet alle ontwikkelingen met een even grote nauwkeurigheid voor een periode van 5 jaar kunnen worden voorspeld. Uit de stapsgewijze invoering van het informatiesysteem, zoals die in hoofdstuk 7 wordt voorgesteld, komt bovendien duidelijk naar voren dat informatie over enkele facetten pas op den duur te verwachten is.

d. Er moet optimaal gebruik worden gemaakt van reeds beschikbare kwantitatieve gegevens.

e. Het informatiesysteem moet een duurzaam karakter hebben. Het gaat om het ontwikkelen van een instrument dat de benodigde gegevens met regelmatige tussenpozen (van een of twee jaar) kan verschaffen op basis van actuele 
inzichten.

f. Het informatiesysteem moet in een gebruiksvriendelijke vorm worden gegoten, zodat de beschikbaar gemaakte gegevens voor een brede groep direct toegankelijk zijn.

\subsection{De variabelen}

Bovengenoemde uitgangspunten betekenen dat het systeem informatie zou moeten opleveren over een groot aantal variabelen betreffende het onderwijs en de arbeidsmarkt. Het informatiesysteem zal in de eerste plaats informatie moeten opleveren over de (dreigende) kwantitatieve discrepanties. Hiervoor is het nodig dat gegevens worden verzameld over de volgende variabelen:

- de werkgelegenheid naar sector, functie, opleiding en leeftijd;

- het personeelsverloop naar sector, functie, opleiding en leeftijd (ten gevolge van VUT, pensioen, AOW en overlijden) en de vervangingsvraag naar sector en functie die daarvan het resultaat is;

- de uitbreidingsvraag (per sector en functie) ten gevolge van de veranderingen in de goederenstromen, in de verpakkingstechniek van de goederen, in de technologie en in de organisatiestructuur;

- de mobiliteit van het personeel tussen de bedrijven en de sectoren in de Rotterdamse haven, vanuit en naar de sectoren buiten de Rotterdamse haven, vanuit en naar de werkloosheid en vanuit en naar de overige bevolking;

- de uitstroom van scholieren en studenten van de te onderscheiden opleidingen en de bestemming van deze uitstroom gedifferentieerd naar functies in de Rotterdamse haven, banen in het overig transport en in andere sectoren, werkloosheid en militaire dienst. De bestemming van scholieren in de Rotterdamse haven zal verder moeten worden gedifferentieerd naar sector, functie en opleiding;

- de bedrijfsinterne verticale en horizontale functiemobiliteit naar opleiding en leeftijd.

In de tweede plaats zal het systeem gegevens moeten opleveren over de (dreigende) kwalitatieve discrepanties. Voor dit doel is informatie nodig over de volgende variabelen:

- de (veranderingen in de) vaardigheden die zijn vereist voor de uitoefening van functies in de verschillende sectoren;

- het niveau, de afstudeerrichting, de opleidingsduur en de globale om- 
schrijving van de inhoud van de te onderscheiden opleidingen;

- de technologische en organisatorische veranderingen en eventuele andere "exogene" factoren.

Hoe al deze factoren onderling samenhangen wordt in het volgende hoofdstuk uitgewerkt. Er zal in dat hoofdstuk een schema worden gepresenteerd van de structuur van het te ontwikkelen informatiesysteem. 


\section{HET INFORMATIESYSTEEM ONDERWIJS-ARBEIDSMARKT IN SCHEMA}

\subsection{Inleiding}

In de Rotterdamse haven is een aantal veranderingen waarneembaar met betrekking tot de omvang, de samenstelling en de inhoud van de werkgelegenheid. Een viertal ontwikkelingen spelen hierbij een cruciale rol.

Allereerst zijn de veranderingen in de omvang en de samenstelling van de internationale goederenstromen via de haven van Rotterdam van invloed op de werkgelegenheid. Deze veranderingen worden onder meer veroorzaakt door de economische ontwikkeling in de herkomst- en de bestemmingsgebieden van de goederenstromen, de veranderingen in het geografische patroon van de internationale handel en de concurrentiepositie van Rotterdam ten opzichte van de andere Westeuropese havens. De verschuivingen in de samenstelling van de goederenstromen komen er voor de Rotterdamse haven op neer dat minder grondstoffen en meer eindprodukten en halffabrikaten worden behandeld. De verwachting is dat het aandeel van bulkgoederen zal afnemen en dat van stukgoederen zal toenemen. Binnen de stukgoedsector zal het zwaartepunt nog meer dan voorheen komen te liggen op de containeroverslag. Dit gaat ten koste van het traditionele stukgoed.

Daarnaast is de technologische ontwikkeling met betrekking tot de aan- en afvoer en de op- en overslag van goederen van invloed op de werkgelegenheid in de Rotterdamse haven. Deze ontwikkeling manifesteert zich in het gebruik van steeds grotere en meer gespecialiseerde zeeschepen, de toenemende containerisering, de vergroting van de werktuigen en in de voortschrijdende automatisering.

Op de derde plaats zijn er consequenties voor de werkgelegenheid van het toenemende logistieke bewustzijn, zoals dat tot uitdrukking komt in de integrale goederenstroombehandeling, de integratie van functies binnen bedrijven, de branchevervaging en in de toenemende koppeling van enerzijds de integrale goederenstroom en anderzijds de bijbehorende informatiestroom.

Tenslotte wordt de omvang en de samenstelling van de werkgelegenheid beïnvloed door de ontwikkeling van de arbeidsorganisatie, zoals de arbeidsextensivering, de verhoging van het scholingsniveau van het personeel, de integratie van de operationele en de administratieve functies en de ontwik- 
keling naar decentrale platte organisatievormen.

De verandering van de omvang en de samenstelling van de benodigde arbeid behoeft niet noodzakelijkerwijs te sporen met de ontwikkeling van de omvang en de samenstelling van het aanwezige personeelsbestand. Het niet parallel lopen van beide ontwikkelingen leidt tot kwantitatieve discrepanties. 0ok kan het voorkomen dat het aanwezige personeel niet beschikt over de voor het uitoefenen van de verschillende functies vereiste kwalificaties of dat hun kwalificaties worden onderbenut. $\mathrm{Er}$ is dan sprake van kwalitatieve discrepanties. In paragraaf 3.3. wordt nader ingegaan op de verschillende soorten discrepanties.

Teneinde deze discrepanties tijdig te kunnen signaleren, zodat snel maatregelen kunnen worden genomen om deze knelpunten uit de weg te ruimen, dient een informatiesysteem onderwijs-arbeidsmarkt te worden ontwikkeld. Hieronder wordt in de vorm van een schema een globale en voorlopige schets gegeven van het te ontwikkelen informatiesysteem. Het schema dient om de elementen waaruit het informatiesysteem moet worden opgebouwd te benoemen en in een onderling verband te plaatsen. Hiermee fungeert het schema dus als aanknopingspunt voor de selectie van de gegevens die moeten worden verzameld en daarmee voor de selectie van de bestaande registratiesystemen die kunnen worden gebruikt bij het opbouwen van het informatiesysteem.

In het schema zijn globaal drie delen te onderscheiden. Rechts is de vraag naar arbeid weergegeven. Het linkerdeel betreft het aanbod van arbeid. Het benedendeel heeft betrekking op de confrontatie van de vraag naar arbeid met het beschikbare aanbod van arbeid. De aanduidingen " $t$ " respectievelijk "t-1" hebben op tijdstippen betrekking, dus $t$ duidt op jaar $t$ en $t-1$ duidt op één jaar daarvoor. In de volgende paragrafen zal het schema worden uitgewerkt en toege 1 icht.

\subsection{Vraag en aanbod}

In het schema is weergegeven dat de vraag naar de produktiefactoren "kapitaal" (investeringsgoederen) en arbeid in belangrijke mate wordt bepaald door de verwachtingen over de toekomstige omvang en samenstelling van de goederenstromen, de verpakkingstechnieken van de stukgoederen, de toekomstige aard en omvang van de begeleidende dienstverlening en informatiestromen en de technologische ontwikkeling. De belangrijkste factoren die 


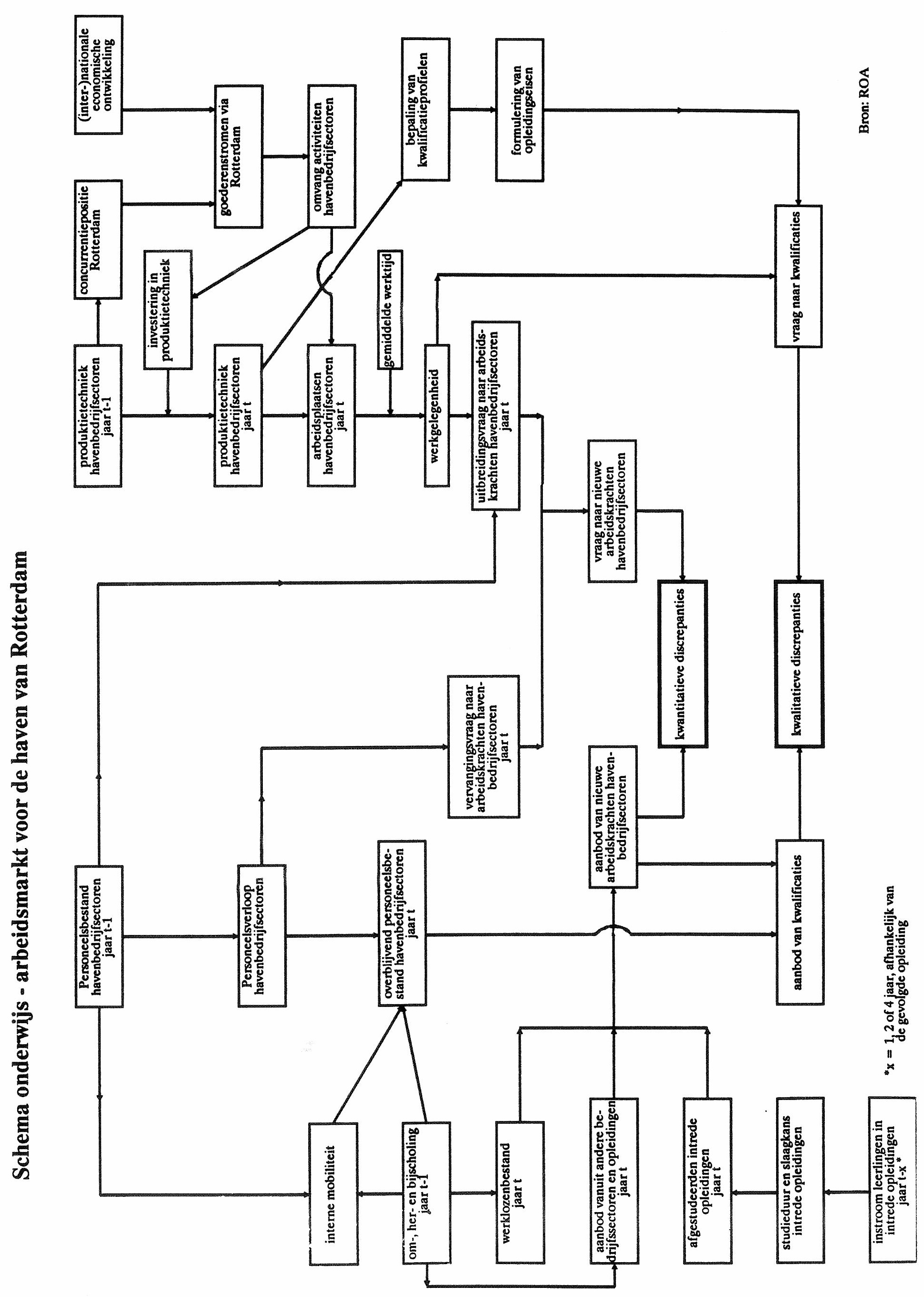


de toekomstige goederenstromen en dienstverlening bepalen zijn reeds in paragraaf 3.1. genoemd. De produktietechniek bepaalt mede de verhoudingen waarin de produktiefactoren zullen worden ingezet. Hierbij gaat het enerzijds om de verhouding tussen kapitaal en arbeid en anderzijds om de verhouding tussen de verschillende soorten arbeid. Binnen bepaalde produktieprocessen zijn echter keuzes mogelijk, bijvoorbeeld voor een machine-gerichte of een mens-gerichte aanpak. De feitelijke keuze die een bedrijf uit de beschikbare produktiefactoren makt, is gebaseerd op de huidige en de verwachte kosten van kapitaal en van de verschillende soorten arbeid, alsmede op de opvattingen die men heeft over een doelmatige organisatie.

De produktietechniek ligt niet voor eens en altijd vast, maar kan op den duur veranderen. Doorgaans is er sprake van een aantal keuze-mogelijkheden die onder meer worden bepaald door het soort goederen dat wordt behandeld en de stand van de technische kennis. Wijzigingen van de toegepaste produktietechniek zullen vooral samenhangen met de verwachte omvang en samenstelling van de te behandelen goederenstromen en dienstverlening, de verpakkingstechnieken, alsmede met het beschikbaar komen van verbeterde versies van bestaande of geheel nieuwe, efficiënter werkende behandelingssystemen.

Het Gemeentelijk Havenbedrijf Rotterdam beschikt over een model voor het maken van lange-termijnprognoses van de ontwikkeling van de goederenstromen via de Rijnmondhavens (zie bijlage 2). Wellicht dat op den duur een koppeling met het informatiesysteem onderwijs-arbeidsmarkt mogelijk is.

De toegepaste produktietechniek kan directe consequenties hebben voor met name de omvang en de aard van de te verrichten werkzaamheden binnen het bedrijf. Deze werkzaamheden worden door bedrijven op basis van de toegepaste organisatieprincipes gebundeld in functies, die elk door een arbeidskracht die over de vereiste kwalificaties beschikt, kunnen worden vervuld. De op grond van de afzetperspectieven, toegepaste technieken en organisatieprincipes vereiste werkzaamheden, bepalen de vraag naar arbeid. De vraag naar arbeid wordt door de bedrijven geformuleerd in termen van gevraagde aantallen arbeidskrachten per functie en de voor de verschillende functies vereiste kwalificaties, waaronder de gevolgde opleiding. De daadwerkelijke vraag naar aantallen arbeidskrachten wordt mede bepald door het ziekteverzuim, de arbeidsduur (de lengte van de dagelijkse werktijd) en de arbeidsperioden (de perioden van de dag dat wordt gewerkt, de dagen in de week en de spreiding over het jaar, vakantiedagen etc.). 
De inhoud van een functie bestaat uit een geheel van taken die min of meer bij elkaar horen en die op de arbeidsplaats in een bedrijf moeten worden verricht. De opleidingseisen worden geformuleerd op basis van de kwalificatieprofielen, die afgeleid kunnen worden uit de functievereisten. De bepaling van de functievereisten en de kwalificatieprofielen vindt mede plaats aan de hand van gegevens (of percepties) over de beroepspraktijk binnen de bedrijfsorganisaties (zie de pijl van produktietechniek naar bepaling van kwalificatieprofielen). De functievereisten kunnen worden onderscheiden naar de mate van fysieke en mentale belasting, de mate van autonomie (eigen invloed op functie-uitoefening) en de vereiste kennis en vaardigheden. Zoals opgemerkt worden op basis van de functievereisten de kwalificatieprofielen geformuleerd. Deze kwalificatieprofielen kunnen worden onderscheiden naar technisch-instrumentele kwalificaties (leervermogen, praktische en theoretische vakkwalificaties) en sociaal-normatieve kwalificaties (identificatie met de werkinhoud, werkhouding en flexibiliteit).

Vervolgens wordt in het schema weergegeven dat het aanbod van arbeid de resultante is van het aanwezige personeelsbestand en de mutaties die zich hierin voordoen ten gevolge van de uitstroom wegens arbeidsongeschiktheid, overlijden, (vervroegde) pensionering en vertrek naar andere sectoren en de instroom, al dan niet na om-, her- en bijscholing, van schoolverlaters, werklozen en werkenden in sectoren buiten de haven. Daarenboven kunnen zich verschuivingen binnen het personeelsbestand voordoen als gevolg van interne mobiliteit (verandering van functie en/of bedrijfssector binnen de haven). Het aanbod van arbeid kan ook worden gezien als een aanbod van kwalificaties, waaronder de genoten opleiding.

Ten aanzien van de instroom uit het onderwijs wordt in het schema aangegeven dat het aantal schoolverlaters wordt bepaald door de omvang van de instroom een periode terug, de studieduur en de slaagkans.

Het "verlies" aan personeelsleden ten gevolge van arbeidsongeschiktheid, overlijden en (vervroegde) pensionering, zal onder normale omstandigheden moeten worden gecompenseerd door het aantrekken van nieuwe arbeidskrachten. De vraag naar nieuwe arbeidskrachten die op deze wijze ontstaat, wordt de vervangingsvraag genoemd. Daarnaast kunnen verschuivingen aan de vraagzijde leiden tot een groei van de vraag naar arbeidskrachten (uitbreidingsvraag). Het saldo van de vervangingsvraag en de uitbreidingsvraag vormt de totale vraag naar nieuwe arbeidskrachten. 


\subsection{Discrepanties}

De volgende factor die in het schema is aangegeven betreft de discrepanties tussen vraag en aanbod. Een confrontatie van de verwachte vraag naar nieuwe arbeidskrachten met het verwachte aanbod kan deze discrepanties aan het licht brengen. Kwantitatieve discrepanties ontstaan wanneer de omvang van de vraag op de arbeidsmarkt niet overeenkomt met de omvang van het aanbod. Daarnaast kunnen ook spanningen optreden tussen de kwalificaties die voor de vervulling van de veranderende functies zijn vereist en de kwalificaties waarover de arbeidskrachten beschikken die deze functies (gaan) vervullen. De laatste vorm van onevenwichtigheid kan worden aangeduid als kwalitatieve discrepantie.

Door tijdig (dreigende) discrepanties te signaleren, is het mogelijk door middel van beleid hierop in te spelen. Tekorten in aantallen arbeidskrachten kunnen dan worden verminderd door het voeren van een actief wervingsbeleid, door het nemen van meer indirecte matregelen die gericht zijn op de verbetering van de concurrentiepositie van de haven of door sturing van de technologische ontwikkeling. Voorzover de genoemde tekorten zich met betrekking tot bepaalde opleidingen voordoen, zou men kunnen besluiten tot het werven van personen met andere opleidingen en tot het stimuleren van de interne mobiliteit (verandering van sector en/of functie binnen de haven). Indien het aanbod van arbeidskrachten de vraag overschrijdt, kunnen maatregelen worden overwogen die zijn gericht op vervroegde uittreding, het stimuleren van vertrek naar sectoren buiten de haven en het aanpassen van de arbeidsduur.

De kwalitatieve discrepanties komen tot uitdrukking in veranderende opleidingseisen. Deze discrepanties kunnen worden verkleind door middel van om-, her- en bijscholing van het aanwezige personeel of van werklozen en door het aanpassen van de leerplannen en de examenprogramma's van het initiële beroepsonderwijs. Hierbij dient echter in ogenschouw te worden genomen dat hogere opleidingseisen niet uitsluitend het resultaat zijn van verzwaring van de inhoud van de werkzaamheden ("upgrading"). Het is mogelijk dat hogere opleidingseisen voor bepaalde functies slechts het gevolg zijn van de ruime beschikbaarheid van hoger gekwalificeerd personeel op de arbeidsmarkt. In dit geval spreekt men van "verdringing", omdat de door lager geschoolden vervulde functies nu worden ingenomen door hoger geschoolden, hoewel de inhoud van deze functies niet is veranderd. 


\section{GRENZEN EN CLASSIFICATIES}

\subsection{De grenzen van het informatiesysteem}

In het vorige hoofdstuk zijn de elementen van het informatiesysteem onderwijs arbeidsmarkt en de relaties tussen deze elementen schematisch weergegeven. Het is de vraag hoe de verschillende elementen kunnen worden gemeten. Hiervoor is het noodzakelijk eerst de grenzen van het informatiesysteem aan te geven. Het gaat hierbij om de antwoorden op de volgende vragen:

- van welke soort bedrijven zal de werkgelegenheid in het informatiesysteem worden opgenomen?

- welke functies worden binnen deze bedrijven in beschouwing genomen?

- welke opleidingen worden onderscheiden?

- welk deel van het werklozenbestand wordt in het informatiesysteem opgenomen?

- op welk geografisch gebied zal het systeem betrekking hebben?

Om tot een zinvolle presentatie van de informatie te kunnen komen, is het noodzakelijk binnen de genoemde populatie van onderzoekseenheden (bedrijven, functies, opleidingen en werklozen) een doelmatige en hanteerbare differentiatie aan te brengen. Hiervoor is het noodzakelijk vast te stellen welke classificatiesystemen het meest adequaat zijn om deze differentiaties in beeld te brengen. In dit hoofdstuk zal worden aangegeven wat de meest geschikte afbakening en classificatie is van de verschillende elementen van het informatiesysteem. Hierbij zal op deze twee punten worden ingegaan met betrekking tot achtereenvolgens het geografisch gebied, de bedrijven, de functies, de opleidingen en de werklozen.

\subsection{De ruimtelijke afbakening}

De bedrijven die relevant zijn voor het te ontwikkelen informatiesysteem onderwijs-arbeidsmarkt zijn niet allemal in het havengebied zelf gevestigd. Bovendien wordt dit gebied in belangrijke gegevensbestanden niet als afzonderlijke regio onderscheiden. Beperking van het onderzoeksgebied tot alleen het havengebied brengt dan ook grote nadelen met zich mee. Om redenen van beschikbaarheid van gegevens is het wenselijk om aan te sluiten bij de gebiedsafbakening die het Gemeentelijk Havenbedrijf Rotterdam hanteert, namelijk het gehele gebied van het voormalig Openbaar Lichaam Rijnmond. Ook binnen het Bedrijven en Instellingen Register Zuid-Holland 
wordt dit gebied als afzonderlijke regio onderscheiden. Derhalve zal voor dit gebied worden gekozen.

Het voormalig Openbaar Lichaam Rijnmond viel samen met het sub-COROP-gebied Rijnmond. Het sub-COROP-gebied Rijnmond vormt een onderdeel van het COROPgebied Groot-Rijnmond ( $n r$. 29). Ter informatie is in bijlage 3 een kaart weergegeven waarop de begrenzing staat aangegeven van het onderzoeksgebied en het COROP-gebied Groot-Rijnmond alsmede een lijst van gemeenten die binnen het onderzoeksgebied (sub-COROP-gebied) en het COROP-gebied GrootRijnmond vallen.

\subsection{De bedrijuen}

Voor het verschaffen van informatie voor een adequaat werkgelegenheids- en scholingsbeleid lijkt het weinig zinvol om alle bedrijven in ogenschouw te nemen die in het gebied van het voormalig Openbaar Lichaam Rijnmond zijn gelokaliseerd. Omdat in het informatiesysteem de relatie onderwijsarbeidsmarkt centraal staat, is het van belang om vooral die activiteiten in beschouwing te nemen, waarvoor voor de uitvoering specifieke, op de haven gerichte, opleidingen nodig zijn. Dit betreft hoofdzakelijk de op- en overslag van goederen en de hieraan gekoppelde administratieve afhandeling.

Volledigheidshalve dient hierbij te worden opgemerkt dat de genoemde afbakening niet geheel overeenkomt met de afbakening die het Gemeentelijk Havenbedrijf Rotterdam hanteert bij de bepaling van de directe havenwerkgelegenheid. In overleg met de opdrachtgever is echter besloten het werkgebied van het informatiesysteem te beperken tot activiteiten die gericht zijn op de op- en overslag van goederen en de administratieve verwerking die dit proces met zich meebrengt. Deze afbakening impliceert dat de transport- en industriële activiteiten die zich op een kade met laad- en losinstallaties bevinden, alsmede de scheepsnieuwbouw en -reparatiewerven buiten de grenzen van het informatiesysteem vallen. Deze beperking is geoorloofd, gezien het geringe belang dat deze activiteiten lijken te hebben voor het haven-gerichte onderwijs.

De hierboven afgebakende groep van bedrijven kan op basis van de hoofdactiviteit nader worden geclassificeerd. Een veelvuldig gehanteerde indeling van bedrijven is de Standaard Bedrijfsindeling van het CBS (SBI). Binnen de SBI worden 9 bedrijfstakken onderscheiden, die weer zijn onderverdeeld in be- 
drijfsklassen (2 digit), bedrijfsgroepen ( 3 digit) en bedrijfssubgroepen (4 digit). De meeste bedrijven die zich bezighouden met de op- en overslag van goederen en de hieraan verbonden administratieve verwerking vallen in de SBI onder bedrijfstak 7 , bestaande uit transport-, opslag- en communicatiebedrijven. Binnen deze bedrijfstak zijn bedrijfsklasse 72 (wegvervoer), 73 (zeevaart), 74 (binnenvaart) en 76 (hulpbedrijven van het vervoer) voor de haven van belang.

Hoewel de SBI wordt gehanteerd in bronnen die voor het informatiesysteem mogelijk van belang zijn, zoals het Bedrijven en Instellingen Register ZuidHolland, de ERBO-enquête van de Kamer van Koophandel, de Arbeidskrachtentelling ( $A K T$ ) en de Enquête Beroepsbevolking (EBB) van het CBS, stuit de toepassing van deze indeling in het informatiesysteem op grote problemen. Zoals in de interne notitie Werkgelegenheid in de Rotterdamse haven door Bosch en Doe (1988) terecht wordt opgemerkt, komen bedrijven die vanuit het oogpunt van de haven zeer verschillende activiteiten verrichten in eenzelfde SBI bedrijfssubgroep terecht. Tank op- en overslagbedrijven, full-containerbedrijven en stukgoedbedrijven, graan op- en overslagbedrijven, maar ook enkele expediteurs en cargadoorsbedrijven vallen bijvoorbeeld binnen één SBI-categorie. Deze bedrijven vertonen grote verschillen wat betreft de afzetontwikkeling, de organisatie van de arbeid en de opleidingseisen die aan de werknemers worden gesteld. Een ander nadeel is dat enkele activiteiten tot verschillende SBI bedrijfssubgroepen behoren. Expediteurs-bedrijven bijvoorbeeld, vallen onder 4 verschillende bedrijfsklassen en onder 10 verschillende bedrijfssubgroepen (Bosch en Doe, 1988). Tenslotte wijzen Bosch en Doe er op dat de SBI-indeling nauwelijks aansluit bij de door het havenbedrijf onderscheiden goederenstromen. In hun notitie wordt vervolgens een alternatief gepresenteerd voor de CBS-classificatie, te weten de "HBsector-code". Deze code is gebaseerd op de door het havenbedrijf onderscheiden goederenstromen. In bijlage 4 wordt de volledige HB-sector-codeindeling weergegeven. Het Gemeentelijk Havenbedrijf Rotterdam heeft de individuele vestigingen met bijbehorende SBI-code, ingedeeld naar HB-sectorcodes.

Door de hierboven genoemde nadelen van de SBI-indeling, geniet de presentatie van de gegevens van het informatiesysteem volgens de HB-sector-codeindeling de voorkeur. Teneinde de gegevens ook te kunnen koppelen aan andere gegevensbestanden, is het wenselijk om in aanvuliing op de HB-sector-code ook de SBI-code van de individuele bedrijven te registreren. Per bedrijf zal 
dan zowel de SBI-code als de HB-sector-code moeten worden bijgehouden. De $H B-s e c t o r e n$ en de HB-sub-sectoren die binnen de voorgestelde selectie vallen zijn weergegeven in tabel 1 .

Tabe1 1. Overzicht van de HB-sector-indeling

\begin{tabular}{|c|c|}
\hline HB-sector & HB-sector code \\
\hline Stuwadoorsbedrijven & 01000 \\
\hline Stukgoed: multipurposebedrijven & 01100 \\
\hline SHB-pool & 01200 \\
\hline Ful1-containerbedrijven & 01300 \\
\hline Ro-ro-stuwadoors & 01400 \\
\hline Graan op- en overslag & 01500 \\
\hline Machinale overslagbedrijven & 01600 \\
\hline Opslag- en distributiebedrijven & 03000 \\
\hline Vemen en pakhuizen & 03100 \\
\hline Tank op- en overslagbedrijven & 03200 \\
\hline Tankopslagbedrijven & 03210 \\
\hline Tankoverslagbedrijven & 03220 \\
\hline Tussenpersonen & 04000 \\
\hline Expediteurs & 04100 \\
\hline Cargadoors & 04200 \\
\hline Geïntegreerde tussenpersonen & 04300 \\
\hline Hulpdiensten t.b.v.het vervoer & 05000 \\
\hline Controlebedrijuen & 05100 \\
\hline
\end{tabular}

Bron: Gemeentelijk Havenbedrijf Rotterdam, 1989

In bijlage 5 wordt per HB-sub-sector weergegeven welke SBI-codes hieronder vallen. Vervolgens wordt in bijlage 6 per HB-sub-sector een overzicht gegeven van het aantal werknemers en het aantal bedrijfsvestigingen dat binnen de desbetreffende sector valt en van de gemiddelde grootte van de vestigingen in de verschillende sectoren. 


\subsection{De functies}

Voor het informatiesysteem onderwijs-arbeidsmarkt zijn alleen de functies interessant waarvoor havengerichte opleidingen worden aangeboden. Dit zijn met name de operationele en de (technisch-) administratieve functies. Louter ondersteunende administratieve en de technische functies, waarvoor opleidingen worden gevraagd die niet specifiek op de haven (of het nat vervoer) zijn gericht, zullen minder gedetailleerd worden beschreven. Teneinde een volledig beeld te verkrijgen van de havengerichte functies, lijkt het wenselijk het informatiesysteem niet te beperken tot alleen de lagere functiegroepen en het middenkader. Wel zal de differentiatie in de hogere functies gering mogen zijn, gezien het relatief kleine aantal personen dat hogere functies uitoefent en de mogelijk minder duidelijke relatie tussen deze functies en de havengerichte opleidingen.

De functies die in de haven voorkomen kunnen worden onderverdeeld in twee hoofdgroepen: ten eerste de operationele functies en ten tweede de (technisch-) administratieve functies. Voor de presentatie van de gegevens van het informatiesysteem onderwijs-arbeidsmarkt is deze tweedeling evenwel te grof en wordt een verdere differentiatie noodzakelijk geacht. De eisen die aan een nieuwe functie-indeling worden gesteld, zijn de volgende:

- de differentiatie van de in het systeem te onderscheiden functies moet zoveel mogelijk aansluiten bij de differentiatie in de havengerichte opleidingen (naar aard en niveau);

- de functie-indeling moet kunnen worden gekoppeld aan de CBS-beroepenclassificatie;

- de functie-indeling moet eventuele functieveranderingen ten gevolge van technologische en organisatorische ontwikkelingen zichtbaar kunnen maken;

- de functie-indeling mag niet te gedetailleerd zijn, omdat het anders moeilijk wordt betrouwbare uitspraken te doen;

- de functies moeten in de praktijk worden onderkend.

Een aantal indelingen van functies en beroepen komt in aanmerking voor gebruik in het informatiesysteem, zoals de CBS-beroepenclassificatie, de ARBI-indeling van het DG ARBVO van het Ministerie van Sociale Zaken en Werkgelegenheid, de functie-indeling gebruikt door van der Wiel en Zimmermann (1985) in hun studie Leerstofafstemming haven-school en de functie-indeling die wordt gehanteerd in het personeelregistratiesysteem van de SVZ. In bijlage. 7 wordt een overzicht gegeven van de genoemde indelingen 
met hun voor- en nadelen. Geen van de genoemde indelingen voldoet echter aan alle hierboven geformuleerde criteria.

Inzicht in de relatie vooropleiding-functie is nodig om te komen tot een verantwoorde functie-indeling die aansluit bij de differentiatie in het opleidingsaanbod. Deze relatie is echter vooralsnog moeilijk te leggen. De meeste opleidingen die door de Stichting Vervoer en Haven Opleidingen worden verzorgd, zijn namelijk niet gericht op de uitoefening van één bepaalde functie, maar zijn bedoeld als oriëntatie op diverse voorkomende werkzaamheden in de haven. Wel wordt binnen de opleidingen een onderscheid gemaakt tussen een operationele en een technisch-administratieve richting. Een uitzondering hierop vormen de opleidingen voor volwassenen (met een baan in de Rotterdamse haven), die worden verzorgd door de Haven- en Vervoersschool "Dr. A.J.T. Stakenburg" en enkele opleidingen die in het kader van het leerlingstelsel worden gegeven, zoals bijvoorbeeld de opleiding tot assistent-cargadoor. Het leerlingstelsel heeft bovendien algemene opleidingen, waarbinnen de cursisten zich kunnen specialiseren door de keuze van bepaalde onderwijsmodules, die eveneens vaak functiegericht zijn. Voor het voltooien van elk van deze modules ontvangt de cursist een deelcertificaat. De verschillende deelcertificaten vormen te zamen het diploma. De opleidingen aan het Hoger Nautisch Onderwijs Rotterdam (maritieme bedrijfsvoering) en aan het Maritiem Instituut "De Ruyter" (opleiding tot havenbedrijfskundige) zijn eveneens breed opgezet, zodat de afgestudeerden uiteindelijk diverse (hogere, coördinerende) functies kunnen vervullen. Hetzelfde kan worden opgemerkt over de opleiding Haven-, Vervoer- en Logistiek Management aan de Hogere Economische School (HES).

Een tweede reden waarom de relatie (voor)opleiding-functie moeilijk te leggen is, hangt samen met het feit dat veel functies "doorgroeifuncties" zijn (Van der Wiel en Zimmermann, 1985). Vaak wordt men in de "uiteindelijke" functie pas aangesteld na opgedane ervaring, bijscholing en interne selectie en promotie. Door interne mobiliteit zijn veel arbeidskrachten van vervuliers van een handmatige functie opgeklommen tot controleurs en bedieners van kleine of grote apparaten (bijv. kraanmachinisten).

Het is van groot belang om de in het informatiesysteem gehanteerde indeling te kunnen vertalen naar de CBS-beroepenclassificatie. De uitkomsten kunnen dan eenvoudig worden vergeleken en in een groter kader geplaatst. Bovendien 
kan hierdoor de bruikbaarheid van de gegevens als "input" voor andere onderzoeken/databestanden worden vergroot. Voor geen van de indelingen is echter een exacte koppeling aan de CBS-beroepenclassificatie mogelijk. Een aantal specifieke functies die in de haven worden onderscheiden, zijn namelijk moeilijk te vertalen naar een standaard-indeling die niet sector-specifiek van aard is. Een beperkte koppeling van de indelingen van de SVZ en in mindere mate ook die van Van der Wiel en Zimmermann aan de CBS-classificatie blijft evenwel mogelijk. In bijlage 8 wordt per SVZ-functie aangegeven naar welke CBS beroepen-code deze zou kunnen worden vertaald.

Zoals hierboven reeds is vermeld brengt de vertaling van de indeling van Van der Wiel en Zimmermann naar de CBS-classificatie een aantal problemen met zich mee. Allereerst is het niet goed mogelijk om binnen de CBS-indeling de categorie "controlerende activiteiten" onder te brengen. Deze categorie bevat namelijk naast de "goederencontrole" ook de "procescontrole". Vooral de laatste activiteit is moeilijk te vertalen naar een CBS-code. Bovendien zijn ook de administratieve functies (cargadoors- en expediteursfuncties) moeilijk in CBS-categorieën onder te brengen. Voor de handfuncties, bedieners van kleine apparaten en bedieners van grote apparaten, is de vertaling daarentegen eenvoudig te maken ${ }^{1}$.

Het aantal categorieën dat binnen de functie-indeling wordt onderscheiden, mag niet te groot zijn, omdat het anders onmogelijk wordt betrouwbare uitspraken over deze functiegroepen te doen. Bovendien is het wenselijk dat de verschillende categorieën ook een weerspiegeling vormen van de verschillende arbeidsmarktsegmenten. Hiermee wordt bedoeld dat het voor een informatiesysteem weinig zinvol is om functies in afzonderlijke categorieën te plaatsen, indien deze onderling zeer goed uitwisselbaar zijn op de arbeidsmarkt. Een tekort in een functiecategorie en een overschot in een andere categorie zou dan een discrepantie suggereren, die zich in werkelijkheid niet zal voordoen. In de indeling van Van der Wiel en Zimmermann wordt een klein aantal functiecategorieën onderscheiden. Ze lijken allemaal betrekking te hebben op verschillende marktsegmenten. In de indeling van de SVZ daarentegen is het totale aantal functiecategorieën dat wordt onderscheiden groot en lijken er enkele onderling uitwisselbaar te zijn op

1. Handfuncties in beroep 9712 (CBS-beroepencode), bedieners kleine apparaten in beroep 9792 (CBS-beroepencode) en bedieners grote apparaten in beroep 9732 (CBS-beroepencode). 
de arbeidsmarkt.

Als laatste voorwaarde voor de te kiezen functie-indeling werd genoemd dat de functies ook in de praktijk als zodanig moeten worden onderkend. De indeling van de SVZ voldoet aan dit criterium. Zoals reeds is vermeld, is deze indeling gebaseerd op CAO-categorieën die in de haven worden gebruikt. Voor wat betreft de indeling van Van der Wiel en Zimmermann lijkt deze voorwaarde ook geen onoverkomelijke problemen op te leveren.

Van de genoemde functie-indelingen lijken de indeling van Van der Wiel en Zimmermann en van de SVZ het meest geschikt om als uitgangspunt voor de functie-indeling van het informatiesysteem onderwijs-arbeidsmarkt te dienen. In tegenstelling tot zowel de CBS-beroepenclassificatie als de ARBIindeling, sluiten de beide eerstgenoemde indelingen goed aan bij de specifieke functies die in de haven worden onderscheiden. De classificatie van Van der Wiel en Zimmermann dekt daarbij een groter deel van de functies die in de haven voorkomen dan de functie-indeling van de SVZ. In tegenstelling tot in de indeling van de SVZ worden door hun ook de administratieve functies bij de cargadoors- en expediteursbedrijven onderscheiden. Het grote voordeel van de indeling van de SVZ is echter dat deze aansluit bij bekende CAO-functies en bovendien wordt gehanteerd in het voor het informatiesysteem uiterst waardevolle personeelregistratiesysteem. Gezien bovengenoemde overwegingen lijkt de indeling van de SVZ het meest bruikbaar voor het verzamelen van de basisgegevens. Voor de verdere analyse van de gegevens lijkt het evenwel wenselijk om een aantal functiecategorieën samen te voegen, althans voor zover er sprake is van uitwisselbare functiegroepen, die tot hetzelfde arbeidsmarktsegment kunnen worden gerekend. De indeling van Van der Wiel en Zimmermann kan hierbij als leidraad fungeren. Wel zal de SVZ-indeling moeten worden aangevuld met de categorieën "staffuncties", "onderhoudsfuncties", "cargadoorsfuncties" en "expediteursfuncties". Eventueel kunnen de laatstgenoemde categorieën verder worden gedifferentieerd.

\subsection{De opleidingen}

De opleidingen die mogelijk relevant zijn voor het informatiesysteem onderwijs-arbeidsmarkt zijn geselecteerd op basis van de Elseviers Beroepen Almanak, de Elseviers Studie Almanak en de Nieuwe Gids voor School en Beroep) en op basis van het overzicht van de Stichting ter Bevordering van 
het Leerlingwezen in het Haven- en Vervoerbedrijf in Nederland. Vervolgens zijn de geselecteerde opleidingsinstituten telefonisch benaderd, om te kunnen bepalen of $z i j$ inderdaad mensen opleiden voor een betrekking in de Rotterdamse haven (zie bijlage 9). Opleidingen die gericht zijn op verkeer, vervoer en logistiek, maar niet specifiek opleiden voor het uitoefenen van werkzaamheden in de haven, kunnen zonder vergaande consequenties voor de representativiteit van het informatiesysteem buiten beschouwing worden gelaten.

Bij zowel het intrede-onderwijs, dat wil zeggen het reguliere dagonderwijs en het leerlingstelsel, als het om-, her- en bijscholingsonderwijs kunnen een aantal opleidingen worden onderscheiden die zijn gericht op de haven. Allereerst verzorgt de Stichting Vervoer en Havenopleidingen (SVH) een aantal dag-opleidingen op LBO- en MBO-niveau die zijn gericht op de uitoefening van operationele of technisch-administratieve werkzaamheden in de haven. Vervolgens worden op HBO-niveau op de Hogere Economische School en in het kader van het Hoger Nautisch onderwijs studenten opgeleid voor een beroep in de haven. Tenslotte organiseert de Stichting ter Bevordering van het Leerlingwezen in het Haven- en Vervoerbedrijf in Nederland een aantal primaire en voortgezette opleidingen in zowel de operationele als de technisch-administratieve sfeer. De opleidingen die binnen het leerlingstelsel worden gegeven in Rotterdam zijn ondergebracht bij de scholen van de Stichting Vervoer en Havenopleidingen (SVH).

Naast de intrede-opleidingen wordt ook een groot aantal havengerichte opleidingen gegeven in de vorm van om-, her- en bijscholing. Een aantal van deze opleidingen is gericht op mensen die reeds werkzaam zijn binnen de haven (vergelijk het schema in hoofdstuk 3). Dit gebeurt deels binnen de bedrijven (bedrijfsopleidingen). Er is echter ook een speciaal opleidingsinstituut dat zich met volwasseneneducatie bezighoudt, $n 1$. de HVS "Dr. A.J.T. Stakenburg". Dit instituut organiseert een groot aantal opleidingen in het kader van het Beroeps Begeleidend Onderwijs (BBO) voor deelcertificaten op primair en secundair niveau en verzorgt een aantal nietgesubsidieerde opleidingen. Voor een overzicht van de opleidingen van de HVS "Dr. A.J.T. Stakenburg" wordt verwezen naar bijlage 10. Tenslotte dient te worden opgemerkt dat het Gewestelijk Arbeidsbureau een cursus voor assistent-expediteur organiseert. Deze opleiding is voor het informatiesysteem onderwijs-arbeidsmarkt van belang. De cursus is speciaal bedoeld voor werklozen en leidt op voor zowel expediteurs- als cargadoorsfuncties. 
In bijlage 11 zijn de opleidingen weergegeven, gedifferentieerd naar niveau en richting. Tevens wordt in deze bijlage het opleidingsinstituut en de formele duur van de opleiding genoemd. De geselecteerde opleidingen sluiten grotendeels aan bij de opleidingen die worden onderscheiden in de Standaard Onderwijs Indeling (SOI) van het CBS. Voor zover mogelijk is de SOI-code van de diverse opleidingsinstituten aangegeven. Voor enkele opleidingen waarvoor nog geen SOI-code bestaat is de RUBS-code aangegeven die te koppelen is aan de SOI-code. De RUBS-code is samengesteld in het kader van de ontwikkeling van een nationale schoolverlatersenquête. Deze enquête zal later nog aan de orde komen.

\subsection{De werklozen}

Zoals in hoofdstuk 3 is aangegeven, zal het werklozenbestand een onderdeel vormen van het potentiële aanbod van arbeid in het informatiesysteem. Het totale werklozenbestand kan in twee groepen worden verdeeld. Allereerst de werklozen die direct een potentieel aanbod vormen voor de Rotterdamse haven en ten tweede de overige werklozen in de regio Rijnmond. De laatste categorie kan alleen op termijn na om-, her- of bijscholing een potentieel aanbod vormen voor de haven. De tweedeling in werklozen kan worden gemaakt op basis van gegevens van het Gewestelijk Arbeidsbureau. Het GAB registreert namelijk onder andere de volgende kenmerken van de ingeschreven werklozen:

- het laatst uitgeoefende beroep;

- de beroepen waarvoor de werkzoekende wil ingeschreven staan (maximaal 3);

- de genoten opleiding (maximaal 3, beginnend bij de hoogste opleiding);

- eventuele gevolgde aanvullende kortlopende cursussen.

De eerste categorie kan worden samengesteld uit werklozen die een opleiding hebben genoten aan een van de in bijlage 11 genoemde opleidingsinstituten of waarvan het laatst uitgeoefende beroep aansluit bij een functie in de haven. Werklozen die niet aan de bovengenoemde criteria voldoen vallen in de tweede categorie.

Het is vanzelfsprekend niet zinvol om alle werklozen in de regio Rijnmond tot het potentiële aanbod voor functies in de Rotterdamse haven te rekenen. Voorgesteld wordt om uitsluitend werklozen die in de eerste categorie vallen in het informatiesysteem op te nemen. Werklozen die niet tot deze groep behoren vallen dus buiten het informatiesysteem, maar kunnen wel nadat zij zich middels om-, of bijscholing bekwaamd hebben in het uitoefenen van een 
functie in de Rotterdamse haven daarin worden opgenomen. Zij worden dan in het informatiesysteem opgenomen via de component om-, her- en bijscholing.

Het GAB classificeert de beroepen volgens de ARBI-indeling (6 digit) en de opleidingen volgens de AROI-indeling van ARBVO. In bijlage 12 zijn de voor de haven relevante beroepen die in de ARBI-indeling worden onderscheiden weergegeven met de bijbehorende code. De selectie van de werklozen op basis van de ARBI en AROI classificatie brengt voor wat betreft de opleidingen het probleem met zich mee dat in de AROI-indeling enkele nieuwe opleidingen ontbreken. De AROI-codes zijn echter wel in grote lijnen te herleiden tot de geselecteerde opleidingen. De koppeling van de ARBI-indeling aan de functieindeling die in het informatiesysteem zal worden gehanteerd, lijkt geen onoverkomelijke problemen op te leveren. 


\section{EVALUATIE VAN DE BENODIGDE GEGEVENS}

\subsection{Inleiding}

De gegevens die voor het opzetten van het informatiesysteem onderwijsarbeidsmarkt nodig zijn, dienen in principe alle elementen te omvatten die zijn opgenomen in het schema dat in hoofdstuk 3 is weergegeven. Dit schema fungeert dus als aanknopingspunt voor de selectie van de gegevens die moeten worden verzameld. De eerste keer zullen niet alleen recente gegevens moeten worden verzameld maar ook historische gegevens. De laatste gegevens zijn nodig om trends te kunnen extrapoleren. De gegevens betreffen zowel de vraag naar arbeidskrachten en het aanbod van arbeidskrachten, als de inhoud van de functies en die van de geselecteerde opleidingen. Met betrekking tot de ontwikkeling van vraag en aanbod op de arbeidsmarkt zal niet alleen de huidige ontwikkeling worden waargenomen maar dient ook een prognose te worden gemaakt van de ontwikkeling op middellange termijn.

In dit hoofdstuk zullen achtereenvolgens de benodigde en beschikbare gegevens over de werkgelegenheid, het onderwijs en de werklozen worden besproken. De vereiste gegevens over de inhoud van functies zullen niet aan de orde komen. Deze zijn namelijk niet aanwezig in de beschikbare gegevensbestanden en zullen middels het op te zetten informatiesysteem moeten worden verzameld.

\subsection{Werkgelegenheidsgegevens}

Allereerst zijn gegevens nodig voor het classificeren van de bedrijven naar de HB-sectorcode en de SBI-code. Hiervoor dient de naam en het adres en de hoofdactiviteit van het bedrijf bekend te zijn.

Ten behoeve van de monitoringfunctie van het informatiesysteem zijn daarenboven per onderscheiden functiecategorie de volgende gegevens nodig:

- aantal in loondienst zijnde medewerkers, in vaste en tijdelijke dienst (excl. uitzendkrachten);

- de opleiding van de medewerkers (zowel de intrede-opleiding als de eventuele om-, her- of bijscholing);

- de leeftijd van de medewerkers;

- de uitstroom van medewerkers als gevolg van VUT, pensionering en WAO;

- de instroom van medewerkers (excl. uitzendkrachten) en de herkomst van 
deze instromers (bedrijfsinterne doorstroom, sectorinterne doorstroom, instroom van werklozen, instroom van buiten de sector werkenden, instroom van verlaters van het intrede-onderwijs naar niveau en richting en naar wel of geen deelname aan het leerlingstelsel, instroom vanuit het volwassenenonderwijs naar richting).

Voor de prognosefunctie van het systeem zijn gegevens nodig met betrekking tot de op middellange termijn te verwachten ontwikkeling van het produktievolume, de toegepaste produktietechniek, de arbeidsduur, de arbeidsperiode en de consequenties hiervan voor het aantal benodigde personeelsleden per functiecategorie en hun vereiste kwalificaties. Deze gegevens moeten hetzij door bevraging van bedrijven of van sleutelfiguren binnen de HB-sectoren worden verzameld, hetzij middels trendextrapolaties worden berekend. Indien trends worden geëxtrapoleerd zijn historische data nodig met betrekking tot de desbetreffende grootheden. Tenslotte moet, met name voor het prognosticeren van de vervangingsvraag, per functiecategorie de leeftijdsstructuur van de werkzame personen bekend zijn.

Tot de bestaande informatiebronnen van werkgelegenheidsgegevens behoren de Statistiek Werkzame Personen (SWP) van het CBS, het Bedrijven en Instellingen Register Zuid-Holland (BIR) van de provincie Zuid-Holland, de Enquête Regionale Bedrijfsontwikkeling (ERBO) van de Kamer van Koophandel en Fabrieken voor Rotterdam en de Beneden-Maas en het personeelregistratiesysteem van de SVZ. In bijlage 13 worden de eerste drie bronnen kort beschreven.

Met uitzondering van het personeelregistratiesysteem van de SVZ zijn bovengenoemde bronnen van werkgelegenheidsgegevens niet of slechts zeer beperkt bruikbaar voor het op te zetten informatiesysteem. In de SWP, het BIR ZuidHolland en de ERBO worden de bedrijven namelijk gecodeerd volgens de SBI van het CBS. Zoals in paragraaf 4.3. naar voren is gebracht, kleven hieraan grote bezwaren. Het grootste nadeel van deze informatiebronnen is echter dat gegevens over het beroep of de functie, de opleiding en de exacte leeftijd van de werkzame personen in het geheel ontbreken. Deze voor het informatiesysteem essentiele gegevens worden wel geregistreerd in het personeelregistratiesysteem van de SVZ.

De SVZ beschikt sinds 1968 over een registratiesysteem van werkzame personen in de vorm van een personeelregistratiesysteem. Dit personeelregistratie- 
systeem wordt beheerd door het centraal personeelsbureau van de SVZ. Het systeem is sinds 1975 geautomatiseerd. Bedrijven die lid zijn van de SVZ zijn verplicht om iedere werknemer die onder een CAO valt waarbij de SVZ contractpartner is, te laten registreren en mutaties door te geven aan het centraal personeelsbureau van de SVZ. CAO-overeenkomsten gelden voornamelijk voor het operationele personeel. Het hogere personeel en het personeel dat werkzaam is in de administratieve sectoren, zoals de expediteurs en de cargadoors, vallen niet onder een $\mathrm{CAO}$, en worden dan ook niet opgenomen in het registratiesysteem.

In het personeelregistratiesysteem worden de bedrijven op basis van hun hoofdactiviteit ingedeeld in 8 sectoren: stukgoedbedrijven, machinaleoverslagbedrijven, containerbedrijven, roll-on/roll-off-bedrijven, graanbedrijven, controle- en expeditiebedrijven, aanverwante bedrijven en de SHB-pool. Deze sectorindeling sluit slechts ten dele aan bij de HB-sectorindeling van het Gemeentelijk Havenbedrijf Rotterdam. Zelfs sectoren waarvan de naam een grote gelijkenis doet vermoeden met de HB-sectoren omvatten deels een andere verzameling van bedrijven. Bovendien komt een aantal sectoren helemaal niet voor in het personeelregistratiesysteem, zoals vemen en pakhuizen, tank op- en overslag, expediteurs, cargadoors en overige tussenpersonen. Het personeel wordt op basis van zijn CAO-functie (er zijn meer dan 100 CAO-functies) eerst geclassificeerd naar de 8 bedrijfssectoren en vervolgens naar functiegroep. De meeste functiegroepen komen in meer dan één sector voor.

In het personeelregistratiesysteem wordt per individuele werknemer een aantal gegevens met betrekking tot onder meer leeftijd, vooropleiding, scholing en functie vastgelegd. Dit gebeurt niet alleen op het moment van aanmelding maar ook bij eventuele mutaties. Wat betreft de genoten vooropleiding dient te worden opgemerkt dat gegevens hierover slechts gedeeltelijk beschikbaar zijn. Alleen het diploma "mat" en de bijscholingscertificaten van de SVH-opleidingen worden gecodeerd. Andere (voor)opleidingen worden wel in het systeem opgenomen, maar kunnen om computertechnische redenen niet worden uitgedraaid. Om een uitgebreidere indruk te kunnen geven van de kenmerken die in het personeelregistratiesysteem worden opgeslagen, is een model van het formulier "Aanmelding en Mutatie Personeel" als bijlage toegevoegd (zie bijlage 14). Gegevens uit het verleden worden wel bewaard, maar de vorm en de inhoud van het formulier zijn 3 à 4 jaar geleden gewijzigd. Historische en recente gegevens zijn in principe voor derden toegankelijk 
op een geaggregeerd niveau, dus zonder dat individuele personen en bedrijven zijn te herkennen.

Gezien de voordelen van het personeelregistratiesysteem van de SVZ ten opzichte van de andere genoemde bronnen van werkgelegenheidsgegevens, ligt het voor de hand gebruik te maken van het personeelregistratiesysteem. Dit impliceert echter dat een aantal gegevens aanvullend moet worden geregistreerd. Het gaat hierbij vooral om werkgelegenheidsgegevens van die bedrijven en/of functies die buiten het personeelregistratiesysteem vallen. In hoofdstuk 6 wordt nader ingegaan op het personeelregistratiesysteem, met name op het gebruik dat hiervan kan worden gemaakt en de consequenties ervan.

\subsection{Onderwijsgegevens}

In het vorige hoofdstuk is uiteengezet welke opleidingen in het informatiesysteem onderwijs-arbeidsmarkt moeten worden opgenomen. Hiervoor dient een aantal gegevens te worden verzameld. Voor het systeem is allereerst informatie nodig over het type, het niveau en de duur van de opleidingen. Voor de reguliere opleidingen en die van het leerlingwezen, alsmede voor de opleiding die door het $G A B$ wordt verzorgd, zijn deze gegevens reeds voorhanden (zie bijlage 11). Van de bedrijfsinterne opleidingen zijn noch over de aard en het niveau, noch over de duur van de opleidingen gegevens beschikbaar.

Er dient ook een globale omschrijving beschikbaar te zijn van de inhoud van de opleidingen. Voor de intrede-opleidingen zijn deze gegevens reeds aanwezig in de vorm van voorlichtingsmateriaal. Van de bedrijfsinterne opleidingen zijn hierover vooralsnog geen gegevens bekend.

Vervolgens zijn gegevens nodig over het aantal leerlingen en afgestudeerden (naar type opleiding, niveau, afstudeerrichting en studiejaar). Het CBS publiceert in de Statistiek van het Beroepsonderwijs gegevens over het aantal leerlingen en geslaagden. Dit betreft echter alleen het reguliere onderwijs. Bovendien zijn recente gegevens nog niet gepubliceerd. Om deze redenen is het van belang dat de scholen dit soort gegevens verstrekken. Bij rondvraag bleek dat alle scholen dergelijke gegevens registreren. Afhankelijk van het oprichtingsjaar van het opleidingsinstitituut zijn ook historische gegevens aanwezig. Met betrekking tot de afgestudeerden is het tevens van belang dat de scholen bijhouden hoeveel leerlingen de school 
zonder diploma verlaten.

Tevens zijn voor het informatiesysteem gegevens over de gemiddelde studieduur en de slaagkans nodig. De scholen zullen deze gegevens beschikbaar moeten stellen ten behoeve van het informatiesysteem onderwijs-arbeidsmarkt.

Daarnaast zijn ook gegevens nodig over de bestemming van de uitstroom. Hierin kan een onderscheid worden gemaakt in werkenden, werklozen, scholieren die verder leren en mensen die niet participeren in de beroepsbevolking en niet doorleren. De bestemming van de werkenden dient nader te worden onderverdeeld naar sector (met behulp van de HB-sector-code voorzover de schoolverlaters in de haven werkzaam zijn en in de overige gevallen met behulp van de SBI-code) en naar functie.

Geen van de scholen registreert dergelijke gegevens over de bestemming van de uitstroom van schoolverlaters. Een mogelijke oplossing hiervoor is de participatie van de reguliere dagopleidingen in het RUBS-project. Het RUBSproject (Registratie van Uitstroom en Bestemming van Schoolverlaters) is een landelijk experiment waaraan de regio Rijndelta deelneemt. De landelijke projectleiding is in handen van het ROA. Het RUBS-project heeft als primaire doelstelling "het ontwikkelen van een landelijk bruikbaar meetinstrument ten behoeve van de registratie van de uitstroom van schoolverlaters en hun positie op de arbeidsmarkt" (LCAS/COA's, 1988, p.4). Hiervoor zal jaarlijks een enquête op steekproefbasis worden gehouden onder schoolverlaters van het reguliere dagonderwijs (voor de vragenlijst zie bijlage 15).

Van de opleidingen die in paragraaf 4.5. zijn geselecteerd, participeert echter alleen de HES in dit project. Het Hoger Nautisch Onderwijs Rotterdam en de SVH-opleidingen nemen momenteel nog niet deel aan het RUBS-project. of deze opleidingen in de toekomst zullen gaan deelnemen is nog niet bekend. Voor de opleidingen die in het kader van het leerlingwezen worden gegeven en die niet onder het RUBS-project vallen, is het noodzakelijk om ten bate van het informatiesysteem zelf een uitstroomenquête te organiseren. De vragenlijst van RUBS zou dan (eventueel na enkele kleine aanpassingen) kunnen worden overgenomen.

Verder zijn gegevens nodig over de omvang van de bijscholing. Een aantal bijscholingscursussen wordt gegeven aan de opleidingsinstituten van de HVS. Indien een kandidaat een dergelijke cursus met succes heeft afgerond, 
ontvangt hij of zij hiervoor een certificaat. De examencommissie van deze scholen houdt een lijst bij van de kandidaten die voor een bepaalde cursus een certificaat hebben behaald en geeft deze gegevens door aan het centraal personeelsbureau van de SVZ. Van de bedrijfsinterne opleidingen zijn daarentegen helaas geen gegevens voorhanden.

Tenslotte zijn gegevens nodig over de huidige functies van de deelnemers aan bijscholingscursussen. Het personeelregistratiesysteem bevat deze gegevens, althans voorzover een bijscholingscursus werd afgesloten met een certificaat van de SVH-opleidingen. Deze gegevens zijn echter zoals reeds is opgemerkt om computer-technische redenen vooralsnog niet op een geaggregeerd niveau beschikbaar. Over de bedrijfsinterne cursussen en de bijscholingscursussen van de werknemers die niet onder het personeelregistratiesysteem vallen, zijn geen gegevens van de huidige functies van de deelnemers bekend.

\subsection{Werkloosheidsgegevens}

In hoofstuk 4 is uiteengezet dat werklozen die een opleiding hebben gevolgd die is gericht op het uitoefenen van een functie in de haven en werklozen waarvan het laatst uitgeoefende beroep aansluit bij een functie in de haven, potentieel aanbod in het informatiesysteem worden opgenomen. Om deze component van het aanbod te kunnen waarnemen zijn de volgende gegevens nodig:

- het aantal werklozen waarvan het laatst uitgeoefende beroep aansluit bij de functies die in de havenbedrijven voorkomen;

- het aantal werklozen dat een opleiding heeft genoten aan een van de havengerichte opleidingen.

Het Gewestelijk Arbeidsbureau beschikt over dit soort gegevens. Het GAB classificeert het werklozenbestand naar zowel het laatst uitgeoefende beroep (ARBI-code), als de genoten opleiding (AROI-code), zodat integratie van deze gegevens in het informatiesysteem mogelijk lijkt. 


\section{NAAR EEN INFORMATIESYSTEEM}

\subsection{Inleiding}

In de voorgaande hoofdstukken is aangegeven uit welke elementen het informatiesysteem kan worden opgebouwd, welke classificaties gehanteerd worden, welke gegevens nodig zijn om de verschillende elementen van het systeem te meten en welke gegevens vooralsnog ontbreken. In dit hoofdstuk wordt ingegaan op de bestaande gegevensbestanden die kunnen worden gebruikt bij het opbouwen van het informatiesysteem en op welke wijze en onder welke condities nog ontbrekende of onvolledige gegevens systematisch en periodiek kunnen worden geregistreerd. Met behulp van de te verzamelen gegevens moet niet alleen inzicht kunnen worden verkregen in de recente ontwikkeling, maar dienen tevens prognoses te kunnen worden gemaakt van de toekomstige ontwikkeling.

Het informatiesysteem kan worden opgebouwd met behulp van de volgende deelsystemen. Op de eerste plaats een monitoringsysteem dat jaarlijks actuele gegevens oplevert over de in de verschillende HB-sectoren werkzame personen, de uitstroom van werkzame personen, de instroom van werklozen, van schoolverlaters en vanuit andere bedrijfssectoren en de arbeidsmarktbestemming van schoolverlaters. Het jaarlijks verzamelen van deze gegevens biedt naar verloop van tijd de mogelijkheid zowel conjuncturele als structurele ontwikkelingen in kaart te brengen. Op de tweede plaats een prognosesysteem dat tweejaarlijks bijgestelde prognoses oplevert van de ontwikkeling van de werkgelegenheid, de vervangingsvraag en de uitstroom uit het onderwijs. Op de derde plaats een systeem waarmee de (toekomstige) veranderingen van de kwalificatieprofielen in kaart kunnen worden gebracht. In dit hoofdstuk zal achtereenvolgens op deze drie deelsystemen worden ingegegaan.

\subsection{Informatie met betrekking tot bedrijven}

\subsubsection{Het monitoringsysteem}

Door middel van het te ontwikkelen monitoringsysteem zullen jaarlijks gegevens worden geregistreerd over de in de HB-sectoren werkzame personen, alsmede over de in- en uitstroom van personeel. Het gaat hierbij om gegevens met betrekking tot de sector waarin de arbeidskrachten werkzaam zijn, de 
functie, de vooropleiding, de leeftijd, en de eventuele om-, her- en bijscholing.

In paragraaf 5.2. is aangegeven dat van de bestaande werkgelegenheidregistraties het personeelregistratiesysteem van de SVZ het meest bruikbaar is voor de ontwikkeling van het informatiesysteem. Maar zoals in het vorige hoofdstuk reeds is vermeld, heeft het gebruik van het personeelregistratiesysteem een aantal beperkingen, zowel wat betreft de dekking van de sectoren en de functies als wat betreft de geregistreerde vooropleiding.

Het gebruiken van het personeelregistratiesysteem ten behoeve van het informatiesysteem onderwijs-arbeidsmarkt voor de haven van Rotterdam heeft een aantal consequenties. Allereerst zijn er consequenties voor de SVZ. De SVZ zal namelijk gegevens van het personeelregistratiesysteem ter beschikking moeten stellen voor onderzoekdoeleinden. Voor de historische gegevens behoeft dit slechts eenmalig te geschieden, bij het opstarten van het informatiesysteem. Vervolgens zal het verstrekken van nieuwe gegevens jaarlijks moeten worden herhaald, teneinde het bestand dat in het informatiesysteem wordt opgenomen te kunnen actualiseren. Het personeelsbureau van de SVZ zal bovendien de gegevens met betrekking tot de opleidingen die niet worden verzorgd door de HVS volledig moeten registreren in een vorm die voor onderzoekdoeleinden geschikt is.

Een tweede consequentie van het gebruik van het personeelregistratiesysteem is dat gegevens moeten worden verzameld over de werkgelegenheid in de bedrijven en de functiegroepen die buiten het personeelregistratiesysteem vallen. Deze gegevens kunnen worden verzameld door de betrokken bedrijven jaarlijks met een, bij voorkeur schriftelijke, enquête te benaderen. Het is uiteraard niet haalbaar om gegevens op het niveau van individuele werknemers te verzamelen. De enquête zal zich daarom beperken tot een aantal vragen per onderscheiden functiecategorie. De vragenlijst die is gebruikt in het "Project Metaal-Electro Zuidwest-Nederland" kan hierbij als richtsnoer dienen (zie bijlage 16). De eerste keer dat deze enquête wordt gehouden moeten wel enkele gegevens over het reeds aanwezige personeelsbestand worden verzameld. Deze zullen het basisbestand vormen dat vervolgens jaarlijks wordt geactualiseerd. Voor de bedrijven die vallen onder het personeelregistratiesysteem kan met een vragenlijst worden volstaan die zich beperkt tot het niet CAO-personeel. 
Bij de eerste keer dat gegevens worden verzameld dienen alle bedrijven te worden benaderd. Het Gemeentelijk Havenbedrijf Rotterdam beschikt over de namen en adressen van de (vestigingen van) bedrijven. Wannneer de structuur van de werkgelegenheid door middel van deze eenmalige integrale benadering bekend is, kan vervolgens bij de kleine bedrijven wellicht worden volstaan met een jaarlijkse steekproef. Hierbij kan eventueel met een roterend systeem worden gewerkt, waarbij van de kleine bedrijven telkens een beperkt en wisselend deel wordt benaderd.

Het personeelregistratiesysteem van de SVZ en de jaarlijkse bevraging van bedrijven zullen de belangrijkste informatiebronnen vormen voor het "monitoren" van de werkgelegenheid. Op basis van het personeelregistratiesysteem en de jaarlijkse bedrijvenenquête, kan een geautomatiseerd bestand van naar sector en functie gedifferentieerde werkgelegenheidsgegevens worden opgebouwd en geactualiseerd.

\subsubsection{Het}

Het prognosesyteem is het onderdeel van het informatiesysteem onderwijsarbeidsmarkt, dat moet worden ontwikkeld voor het maken van de middellangetermijnprognoses. De mogelijke benaderingen om prognoses te maken van de vervangingsvraag en de uitbreidingsvraag zullen achtereenvolgens worden beschreven.

De toekomstige vervangingsvraag naar arbeid, gedifferentieerd naar sector en functie, wordt in hoofdzaak bepald door de leeftijd van de personen die werkzaam zijn in de onderscheiden sectoren en functies, alsmede door de regelgeving met betrekking tot de (vervroegd) pensioengerechtigde leeftijd. Daarnaast spelen ook de arbeidsongeschiktheid en de mortaliteit bij de bepaling van de vervangingsvraag een rol. Gegevens over de leeftijdsopbouw van het personeelsbestand dat werkzaam is in de onderscheiden sectoren en functies kunnen worden verzameld en geregistreerd met behulp van het eerder geschetste monitoringsysteem.

Voor het bepalen van de toekomstige ontwikkeling van de omvang en de samenstelling van de uitbreidingsvraag zijn verschillende methoden mogelijk, die al dan niet in combinatie kunnen worden gebruikt. Periodieke bevraging van bedrijven of van sleutelfiguren binnen sectoren behoort tot de mogelijk- 
heden. Ook kan worden gewerkt met trendextrapolaties of econometrische modellen.

Bij de bevraging van bedrijven kan van een soortgelijke vragenlijst gebruik worden gemaakt als bij het eerder genoemde "Project Metaal-Electro ZuidwestNederland". Bij dit project wordt tweejaarlijks een vragenlijst gehanteerd met extra vragen over de middellange-termijnperspectieven.

Bij enquêtering van een groot aantal bedrijven ligt een schriftelijke bevraging om praktische redenen voor de hand. Het voordeel hiervan is dat de benodigde informatie op uniforme wijze en relatief goedkoop wordt geregistreerd en snel kan worden verwerkt. Het nadeel is dat bedrijven vaak huiverig zijn om de in hun ogen strategische bedrijfsinformatie aan derden te verstrekken. Dit nadeel kan deels worden ondervangen door een aantal van te voren opgestelde toekomstscenario's aan de bedrijven voor te leggen en te vragen welk scenario op hun bedrijf van toepassing is.

Een eenvoudiger methode is om in plaats van bedrijven sleutelfiguren binnen sectoren te vragen elke twee jaar hun visie te geven op de middellangetermijnontwikkelingen binnen hun sector met betrekking tot het produktievolume en de toegepaste produktietechniek, alsmede de consequenties hiervan voor de omvang en samenstelling van de werkgelegenheid binnen hun sector. $B i j$ het inventariseren van de visie van sleutelfiguren kan eventueel gebruik worden gemaakt van bestaande netwerken.

Het gebruiken van sleutelfiguren binnen sectoren als informatiebron heeft twee voordelen boven een benadering van individuele bedrijven. Op de eerste plaats biedt dit de mogelijkheid tot mondelinge bevraging, individueel of in groepsbijeenkomsten, waarbij veel uitgebreider en dieper op de vragen kan worden ingegaan. Op de tweede plaats kunnen deze informanten vrijer spreken over de sectorontwikkeling dan bedrijven dat kunnen over de bedrijfsontwikkeling. Nader onderzoek dient uit te maken welke informatiebron de voorkeur verdient.

Omdat het bij middellange-termijnprognoses gaat om de structurele ontwikkeling is een jaarlijkse bevraging niet nodig en kan, zoals reeds is opgemerkt, worden volstaan met een tweejaarlijkse bevraging. Bovendien kan, evenals bij het monitoringsysteem, met een roterend systeem worden gewerkt, waarbij van de kleine bedrijven telkens een beperkt en wisselend deel wordt 
benaderd.

De derde methode houdt in dat de middellange-termijnontwikkeling van de werkgelegenheid wordt geprognostiseerd op basis van trendanalyses of door het toepassen van econometrische modellen. Een voorwaarde hiervoor is dat geschikte inputgegevens beschikbaar zijn of beschikbaar komen. Het goederenstromenmodel waarover het Gemeentelijk Havenbedrijf Rotterdam beschikt zou kunnen dienen als een inputgegeven voor de te ontwikkelen modellen. Het goederenstromenmodel wordt in in bijlage 2 besproken.

Met het ontwikkelen van econometrische modellen en het genereren van de hiervoor benodigde inputgegevens is veel tijd gemoeid. Een relatief snel te verwezenlijken aanpak zou zijn het combineren van trendextrapolatietechnieken met het toetsen van de resultaten hiervan aan de opinies van een panel van sleutelfiguren. In een gefaseerde aanpak zouden de toegepaste methoden en technieken daarna kunnen worden verfijnd. Wel is het pas mogelijk om prognoses op te stellen als het monitoringsysteem is ontwikkeld en goed functioneert.

\subsection{Informatie over kwalificatieprofielen}

Een onderdeel van het informatiesysteem onderwijs-arbeidsmarkt wordt gevormd door het systeem waarmee veranderingen in de kwalificaties, die voor de uitoefening van de onderscheiden functies zijn vereist, kunnen worden waargenomen. Dit zou kunnen geschieden door telkens voor een deel van de functies, volgens een roterend systeem, informatie te verzamelen. Niet alleen de werkzaamheden die door de beoefenaren van de functies worden verricht dienen te worden waargenomen, maar ook en vooral de door deskundigen verwachte veranderingen in de functie-inhoud als gevolg van veranderingen van de toegepaste produktietechniek.

De informatieverstrekkers kunnen worden gekozen met behulp van een getrapte steekproef. Hierbij worden eerst de bedrijven geselecteerd, rekening houdend met het aantal werkzame personen, de aanwezige functies en de toegepaste produktietechniek. Vervolgens worden de informanten binnen de bedrijven geselecteerd.

In een later stadium van de ontwikkeling van het informatiesysteem kan worden getracht een verband te leggen tussen de verandering van de functie- 
eisen en de (verwachte) technologische veranderingen in de havenbedrijven. Van de technologische veranderingen die zich bij de bedrijven voltrekken zouden dan eerst indicatoren moeten worden ontwikkeld. Deze kunnen dan vervolgens worden geprognosticeerd.

\subsection{Informatie over opleidingen}

\subsubsection{Het monitorings}

Een deel van het informatiesysteem zal jaarlijks gegevens moeten opleveren over de aantallen schoolverlaters naar richting en niveau, het al dan niet hebben van een diploma en over de bestemming van de schoolverlaters. Gegevens over de aantallen schoolverlaters zullen jaarlijks moeten worden verstrekt door de geselecteerde scholen. Het GAB Rotterdam zal bereid moeten zijn om jaarlijks door te geven hoeveel werklozen zijn omgeschoold voor de uitoefening van functies binnen de haven en wat hun bestemming is. Om de bestemming van de schoolverlaters te kunnen registreren, zullen de scholen bereid moeten zijn om te participeren in het RUBS-project (zie hoofdstuk 5) of in een vergelijkende schoolverlatersenquête. Het COA Rijndelta, dat het RUBS-project uitvoert, zal bereid moeten zijn om de vragenlijst uit te breiden en/of te zorgen voor een hercodering naar de $\mathrm{HB}-$ sector-code en de voorgestelde functie-indeling.

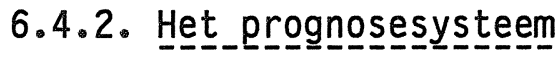

Bij de opleidingen die vier jaar duren kunnen de aantallen afgestudeerden in "jaar $t+4$ " worden voorspeld op basis van het aantal instromers in "jaar $t$ ". Niet alle instromers doen echter exact vier jaar over de opleiding en niet alle instromers verlaten gediplomeerd de opleiding. Dit betekent dat bekend moet zijn hoeveel procent van alle instromers de opleiding gediplomeerd verlaten en hoe lang de gediplomeerden gemiddeld over de opleiding doen. Deze gegevens zullen per afstudeerrichting over een groot aantal jaren bekend moeten zijn. De geselecteerde scholen zullen bereid moeten zijn om deze gegevens ter beschikking te stellen van het informatiesysteem.

Bij een prognosetermijn van vijf jaar zal voor opleidingen die één of twee jaar duren ook het aantal instromers in de eerstkomende vier respectievelijk drie jaar moeten worden geprognosticeerd voordat volgens dezelfde 
systematiek het aantal afgestudeerden kan worden voorspeld. Ten behoeve van de prognose van de instroom zijn gegevens nodig over de opbouw van de regionale bevolking naar leeftijd en geslacht, alsmede historische gegevens over de deelname van de leeftijdspecifieke groepen aan de havengerichte opleidingen. 


\section{OPZET EN FASERING VAN HET ONDERZOEK}

\subsection{Voorgestelde werkwijze}

Het informatiesysteem onderwijs-arbeidsmarkt kan op verschillende manieren worden ontwikkeld. Een voor onderzoekers aantrekkelijke manier is om het systeem te zien als een groot bouwwerk dat steen voor steen wordt opgetrokken en dat pas voor gebruik gereed is als de laatste voorzieningen zijn aangebracht. Deze benadering heeft echter een groot nadeel. Pas na een aantal jaren zal het voor potentiële gebruikers duidelijk worden wat men van het systeem mag verwachten ten aanzien van zowel de aard als de kwaliteit van de op te leveren informatie. Inmiddels kunnen de prioriteiten zijn verlegd of kan blijken dat een andere aanpak tot een kwalitatief beter resultaat zou leiden.

Een tweede manier is om het systeem in fasen op te zetten. Een logische fasering zou dan zijn om achtereenvolgens de volgende onderdelen te ontwikkelen. Op de eerste plaats het monitoringsysteem met betrekking tot de actuele situatie op de arbeidsmarkt en in het onderwijs, vervolgens de methoden voor het maken van prognoses van de middellange-termijnontwikkeling van vraag en aanbod op de arbeidsmarkt en de uitstroom uit het onderwijs en tenslotte de instrumenten voor het registreren en voorspellen van veranderingen in de functiekwalificaties en de opleidingseisen. Hoewel bij deze aanpak reeds in een vroeg stadium volledige informatie beschikbaar komt over de actuele situatie op de arbeidsmarkt en in het onderwijs, kan pas in een latere fase inzicht worden verschaft in de ontwikkelingen op de middellange termijn. Informatie over de inhoudelijke aspecten van functies en opleidingen is in deze aanpak nog later te verwachten.

Bovenvermelde nadelen kunnen worden vermeden door beide benaderingen te combineren. Het informatiesysteem wordt dan fasegewijs ontwikkeld voor een in eerste instantie beperkt deel van de havenactiviteiten. Vervolgens zullen meer activiteiten aan het systeem worden toegevoegd tot uiteindelijk een compleet beeld van de arbeidsmarkt van de haven van Rotterdam en het onderwijs kan worden verschaft. Het ligt voor de hand de activiteiten die deel uitmaken van het personeelregistratiesysteem van de SVZ bij deze aanpak als startpunt te kiezen. De voordelen van deze benadering zijn dat al snel over beleidsrelevante informatie ten aanzien van alle facetten van het informatiesysteem kan worden beschikt en dat reeds in een vroeg stadium 
mogelijke spanningen tussen wenselijkheden en mogelijkheden kunnen worden gesignaleerd. Deze discrepanties hebben dan nog slechts betrekking op een beperkt en overzichtelijk deel van het totale informatiesysteem. Een mogelijk nadeel van deze aanpak is dat men het zicht zou kunnen verliezen op de vraag hoe de in het desbetreffende stadium bereikte resultaten zich verhouden tot het volledige informatiesysteem, zoals dat uiteindelijk beschikbaar zal moeten komen. Om dit gevaar te voorkomen is het noodzakelijk dat bij de uitvoering van het project regelmatig een terugkoppeling plaatsvindt van de tot dusver bereikte resultaten naar het systeem dat als uiteindelijk te bereiken doel wordt nagestreefd. Voorgesteld wordt om het informatiesysteem te ontwikkelen op de wijze die hiervoor als derde mogelijkheid is geschetst.

In de volgende paragrafen zal de laatstgenoemde aanpak om het informatiesysteem te ontwikkelen verder worden uitgewerkt. Eerst wordt in paragraaf 7.2. een overzicht gegeven van de delen waaruit het informatiesysteem zal bestaan in zijn uiteindelijk te bereiken vorm. Daarna worden in paragraaf 7.3. de stappen aangegeven die achtereenvolgens moeten worden ondernomen om de uiteindelijke vorm te bereiken. Tenslotte wordt in paragraaf 7.4. ingegaan op enkele organisatorische aspecten die zijn verbonden aan de uitvoering van het project.

\subsection{De onderdelen van het informatiesysteem}

In het te ontwikkelen informatiesysteem onderwijs-arbeidsmarkt kunnen drie delen worden onderscheiden: het monitoringsysteem, het prognosesysteem en het systeem van kwalificatieprofielen. De drie deelsystemen zullen onderstaand worden beschreven en tevens zal worden aangegeven op welke wijze en via welke instantie de voor elk deelsysteem benodigde gegevens kunnen worden verzameld.

De basis van het informatiesysteem zal worden gevormd door het monitoringsysteem met betrekking tot de actuele arbeidsmarkt, de geselecteerde opleidingen en de onderscheiden functiecategorieën. De elementen waaruit dit systeem zal worden opgebouwd, zijn schematisch weergegeven in hoofdstuk 3. Het monitoringsysteem zal jaarlijks actuele gegevens moeten opleveren over de ontwikkelingen op de arbeidsmarkt, met name over de werkgelegenheid, het personeelsverloop, de scholingsactiviteiten, de uitstroom uit het onderwijs, de werving van schoolverlaters, het aanbod van werklozen en de instroom van 
personen vanuit andere bedrijfssectoren.

Teneinde het monitoringsysteem te kunnen ontwikkelen zullen eenmalig "historische" gegevens moeten worden verzameld voor de elementen die in het systeem worden onderscheiden. Vervolgens zal het systeem jaarlijks moeten worden geactuali iseerd.

Voor het welslagen van het onderzoek is een actieve bijdrage van de in de regio gevestigde bedrijven en instellingen van cruciaal belang. Voorgesteld wordt om het werkgelegenheidsdeel van het monitoringsysteem voorlopig te beperken tot het personeelregistratiesysteem van de SVZ. De bedrijven worden dan zo min mogelijk belast met verzoeken om gegevens die zij reeds aan de SVZ hebben verstrekt en bovendien kan gebruik worden gemaakt van een bestand dat reeds in een geautomatiseerde vorm aanwezig is. De SVZ zal dan bereid moeten zijn om in het personeelregistratiesysteem de genoten vooropleiding beter te registreren, ook met betrekking tot het reeds aanwezige personeel.

Voor de verdere uitbouw van het systeem wordt van de bedrijuen die tot de geselecteerde HB-sectoren behoren verwacht dat zij bereid zijn jaarlijks aan een enquête mee te werken. Aan de bedrijven zullen dan onder meer vragen worden voorgelegd over het aanwezige personeelsbestand naar leeftijd, opleiding en functie, de arbeidsongeschiktheid, de mortaliteit, (vervroegde) pensionering, de leeftijd waarop de werknemers met (vervroegd) pensioen gaan en de instroom van nieuwe medewerkers. Tevens zal in deze enquête naar de om-, her- en bijscholingsactiviteiten van de werknemers worden gevraagd. Zoals reeds is opgemerkt zal in eerste instantie worden volstaan met de bedrijven die vallen onder het personeelregistratiesysteem van de SVZ. Voor deze bedrijven kan met een beperkte vragenlijst worden volstaan.

Ook van de scholen is voor het slagen van het project een actieve bijdrage noodzakelijk. Zij zullen bereid moeten zijn jaarlijks gegevens te leveren over de aantallen afgestudeerden, gedifferentieerd naar opleidingsrichting. Tevens is van belang dat de scholen participeren in het RUBS-project of in een vergelijkbare schoolverlatersenquête, zodat de resultaten van deze enquête kunnen worden opgenomen in het informatiesysteem.

Als de scholen participeren in de RUBS-enquête zal het COA-Rijndelta, dat verantwoordelijk is voor het uitzetten en coderen van deze enquête in de regio Rijndelta, bereid moeten zijn om enige aanpassingen in de codering van 
de sectoren aan te brengen en de vragenlijst voor de geselecteerde scholen uit te breiden met een vraag naar de (CAO-) functie.

Tenslotte wordt van het Gewestelijk Arbeidsbureau verwacht dat het jaarlijks gegevens verstrekt over het aantal geregistreerde werklozen, in het bijzonder het aantal werklozen dat hetzij werkzaam is geweest in beroepen die nauw aansluiten bij de functies die in de haven voorkomen, hetzij een opleiding heeft genoten aan een van de geselecteerde opleidingen. Daarnaast zal het GAB ook gegevens moeten leveren over de deelname aan om-, her- en bijscholingscursussen, die zijn gericht op het uitoefenen van een functie binnen de haven, alsmede over de geregistreerde vacatures.

Het tweede deel van het informatiesysteem betreft het prognosesysteem. Hiervoor zullen allereerst eenvoudige modellen worden gemaakt voor de prognose van min of meer autonome processen, zoals de vervangingsvraag en de uitstroom uit het onderwijs. Vervolgens zullen methoden worden ontwikkeld voor de prognose van de uitbreidingsvraag.

De gegevens die nodig zijn voor de prognose van de vervangingsvraag kunnen grotendeels direct worden ontleend aan het monitoringsysteem. Voor het bepalen van de vervangingsvraag is het namelijk van cruciaal belang de leeftijdsopbouw van het aanwezige personeelsbestand te weten, alsmede de (vervroegde) pensioengerechtigde leeftijd, de omvang van de arbeidsongeschiktheid en de mortaliteit.

Teneinde de toekomstige uitstroom uit het havengerichte onderwijs te kunnen prognosticeren dienen de geselecteerde opleidingen gegevens te verstrekken over de (te verwachten) instroom in het onderwijs, het aantal leerlingen per studiejaar, de gemiddelde studieduur en de slaagkans. Op basis van het aantal eerstejaars leerlingen, in combinatie met de gemiddelde studieduur en de slaagkans, kan dan de omvang van de uitstroom op de middellange termijn worden bepaald.

Voor de kortere opleidingen, die onder andere in het kader van het leerlingwezen worden gegeven, is het cohort dat zich over vier à vijf jaar op de arbeidsmarkt zal aanbieden nog niet aan de opleiding begonnen op het moment dat de prognoses worden gemaakt. De gegevens over de toekomstige instroom van deze opleidingen zullen dan ook op een andere wijze moeten worden geprognosticeerd. Hiervoor zijn gegevens nodig over de bevolking naar 
leeftijd en geslacht en de deelnamepercentages van de verschillende opleidingen.

Prognoses van de uitbreidingsvraag kunnen worden samengesteld op basis van trendanalyses, het toepassen van econometrische modellen, of door het peilen van de toekomstperspectieven bij bedrijven of sleutelpersonen in sectoren, dan wel door een combinatie van deze methoden. Voorzover in het prognosesysteem gebruik wordt gemaakt van informatie afkomstig van bedrijven moeten deze om het jaar meewerken aan een enquête over onder meer de toekomstperspectieven van het bedrijf of van de sector waartoe zij behoren. Hierbij zal een onderscheid worden gemaakt naar bedrijfsgrootte. Bij het inventariseren van de toekomstperspectieven bij sleutelpersonen in sectoren kan eventueel gebruik worden gemaakt van bestaande netwerken.

Het monitoringsysteem en het prognosesysteem zullen vervolgens moeten worden geïntegreerd tot een gebruiksvriendelijk informatiesysteem.

Het derde deel van het informatiesysteem onderwijs-arbeidsmarkt betreft de beschrijving en de prognose van de inhoud van functies en de te stellen opleidingseisen. Tevens zullen in dit deel van het informatiesysteem de (dreigende) discrepanties tussen de voor de functievervulling vereiste en de bij de vervullers van deze functies beschikbare kwalificaties zichtbaar moeten worden gemaakt. Deze informatie zal uiteindelijk moeten worden geïntegreerd met de beide andere delen van het informatiesysteem.

Voor dit deel van het systeem zullen de bedrijven tweejaarlijks worden benaderd voor informatie over de technologische- en organisatorische ontwikkelingen die zij binnen hun bedrijf of sector op de middellange termijn verwachten, alsmede over de inhoud van de functies, de vereiste functiekwalificaties en de verwachte veranderingen hierin. Tevens zal worden gevraagd naar de opleidingskwalificaties van het aanwezige personeel. Grote bedrijven zullen integraal moeten worden benaderd. Voor kleine bedrijven kan worden volstaan met een (roterende) steekproef. De bij het personeel aanwezige en de voor de functies vereiste kwalificaties zullen, zoals reeds is opgemerkt, met elkaar moeten worden geconfronteerd. 


\subsection{Ontwikkelingsfasen van het informatiesysteem}

Zoals in paragraaf 7.1. is voorgesteld zal het informatiesysteem onderwijsarbeidsmarkt voor de Rotterdamse haven in een aantal fasen worden ontwikkeld. Elke fase zal voor beleidsdoeleinden relevante produkten moeten opleveren. De globale aanpak zal zijn dat met de ontwikkeling van enkele onderdelen van het informatiesysteem gelijktijdig zal worden begonnen, maar deze zich vooralsnog zullen beperken tot slechts dat deel van de bedrijven in de Rotterdamse haven dat is opgenomen in het personeelregistratiesysteem van de SVZ. Vervolgens kan het informatiesysteem in de opeenvolgende ontwikkelingsfasen worden verbreed tot de arbeidsmarkt van alle bedrijven binnen het sub-COROP-gebied Rijnmond die direct met de haven zijn verbonden. De voorgestelde stapsgewijze ontwikkeling van het informatiesysteem kan als volgt worden uitgewerkt.

In de eerste fase zullen de volgende activiteiten worden ontplooid:

- Het personeelregistratiesysteem van de SVZ zal worden ontwikkeld tot een geautomatiseerd systeem dat jaarlijks representatieve en actuele informatie verschaft over (mutaties van) de werkgelegenheid naar sector en enkele kenmerken van het personeel zoals functie, opleiding en leeftijd. Hiervoor is vanzelfsprekend de medewerking van de SVZ vereist, die een aantal aanpassingen van het personeelregistratiesysteem, bijvoorbeeld ten aanzien van de onderwijsgegevens, zal moeten doorvoeren. Het ROA kan hierbij adviseren over de aard en de classificatie van de gegevens die voor het informatiesysteem onderwijs-arbeidsmarkt nodig zijn, alsmede over de opzet van een te ontwikkelen standaardrapportage met betrekking tot deze gegevens.

Het is mogelijk dat zich ten aanzien van de functionering van het personeelregistratiesysteem enkele automatiseringsproblemen zullen voordoen waarvoor advies bij derden zal moeten worden ingewonnen.

- In het kader van de werkzaamheden aan het personeelregistratiesysteem van de SVZ zal worden getracht aan dit systeem historische gegevens te ontlenen waarmee ontwikkelingstrends kunnen worden aangegeven.

- Er zal een nauwkeurige inventarisatie worden uitgevoerd van de bedrijven en functies die buiten het personeelregistratiesysteem van de SVZ vallen maar wel deel zouden moeten uitmaken van het informatiesysteem onderwijsarbeidsmarkt.

- Bij de opleidingen die deel zullen uitmaken van het informatiesysteem onderwijs-arbeidsmarkt (zie hoofdstuk 4) zullen gegevens worden verzameld 
over de in-, door- en uitstroom van leerlingen. Er zullen door het ROA voorstellen worden gedaan voor de opzet van een jaarlijks te houden enquête onder de pas afgestudeerden van deze opleidingen met betrekking tot hun bestemming op de arbeidsmarkt. Indien mogelijk zal worden aangesloten bij de door het COA-Rijndelta jaarlijks te houden RUBSenquête. De resultaten van de in mei 1989 gehouden enquête worden geanalyseerd ten aanzien van de bestemming van de afgestudeerden, alsmede ten aanzien van de aanpassingen die in deze enquête noodzakelijk zijn om een goede aansluiting te waarborgen tussen de classificaties bij RUBS en bij het informatiesysteem onderwijs-arbeidsmarkt.

Het is duidelijk dat voor de uitvoering van deze werkzaamheden alsmede voor het aanpassen van de vragenlijst en van de codering, de medewerking van de opleidingen en het COA-Rijndelta is vereist. In het bijzonder geldt dit voor het ter beschikking stellen van de ingevulde enquêteformulieren voor het uitvoeren van de analyses die hierboven zijn genoemd.

- Er zal een meetinstrument worden ontwikkeld om de profielen van functies en de daaraan verbonden opleidingseisen te bepalen. Het meetinstrument moet indicaties kunnen geven van significante veranderingen op middellange termijn in de kwalificatie-eisen die aan het personeel worden gesteld. Het te ontwikkelen instrument moet zich lenen voor regelmatige toepassing in schriftelijke enquêtes onder bedrijven. Het meetinstrument zal worden uitgetest bij enkele functiecategorieën in een sector die tamelijk volledig is opgenomen in het personeelregistratiesysteem van de SVZ. Het ligt voor de hand hiervoor functiecategorieën te kiezen die een belangrijke bestemming vormen voor de afgestudeerden van de opleidingen die expliciet worden onderscheiden in het informatiesysteem onderwijs-arbeidsmarkt.

Voor het ontwikkelen en het uittesten van het hier bedoelde meetinstrument wordt voorgesteld om een hierin gespecialiseerd onderzoekbureau in te schakelen.

- Deze ontwikkelingsfase zal worden afgesloten met een door het ROA te verzorgen onderzoeksverslag, waarin uitgewerkte voorstellen zullen zijn opgenomen voor de tweede ontwikkelingsfase. Hierbij zal met name worden ingegaan op de mogelijke uitbreiding van het informatiesysteem met gegevens van bedrijven die geen deel uitmaken van het personeelregistratiesysteem van de SVZ. In het nu volgende wordt er vooralsnog van uit gegaan dat deze uitbreiding in de derde fase zal plaatsvinden.

Voor de invulling van de tweede ontwikkelingsfase zijn de resultaten en 
bevindingen van de eerste fase vanzelfsprekend van groot belang. Daarom moet thans worden volstaan met slechts een globale aanduiding van de te verrichten activiteiten in de tweede fase.

- Er zal een vragenlijst worden ontwikkeld ten behoeve van de jaarlijkse enquêtering van de bedrijven met betrekking tot de niet in het personeelregistratiesysteem opgenomen gegevens die voor het informatiesysteem onderwijs-arbeidsmarkt van belang zijn (zie hoofdstuk 6). Vervolgens zal deze enquête worden uitgevoerd onder de bedrijven die in het personeelregistratiesysteem van de SVZ zijn opgenomen. Waarschijniijk kan bij de kleine bedrijven met een (roterende) steekproef worden volstaan.

- Het in de eerste fase ontwikkelde meetinstrument om (veranderingen in) kwalificatieprofielen van functies vast te stellen, zal vooralsnog op een beperkt aantal functies worden toegepast. Daarbij wordt gedacht aan $20 \%$ van het aantal functiecategorieën.

- Er zullen door het ROA extrapolatietechnieken worden ontwikkeld voor het maken van middellange-termijnprognoses (vijf jaar) van de (ontwikkeling van de) werkgelegenheid, het personeelsbestand en de uitstroom uit het onderwijs. Deze prognoses zullen worden getoetst aan de opinies van sleutelpersonen uit de onderscheiden sectoren van het informatiesysteem. Daarna worden definitieve prognoses door het ROA opgesteld.

- Door het ROA zal een standaard rapportage worden ontwikkeld ten aanzien van de jaarlijks te actualiseren monitoringgegevens, de tweejaarlijks te actualiseren prognosegegevens en van de jaarlijks te actualiseren gegevens over de kwalificatieprofielen van een deel van de functies. De basisgegevens voor deze rapportage zullen worden opgenomen in een gebruiksvriendelijk geautomatiseerd systeem. Voorgesteld wordt hierbij een bureau in te schakelen dat reeds met de ontwikkeling van soortgelijke systemen ervaring heeft.

Deze ontwikkelingsfase wordt afgesloten met het uitbrengen van rapportages over de resultaten en bevindingen en het presenteren van een uitgewerkt voorstel voor de derde ontwikkelingsfase. Het ligt voor de hand dat op dit moment slechts enkele suggesties kunnen worden gedaan met betrekking tot de activiteiten die in deze ontwikkelingsfase kunnen plaatsvinden. In hoeverre het informatiesysteem zal worden uitgebreid met bedrijven die niet zijn opgenomen in het personeelregistratiesysteem van de SVZ is een belangrijk beslispunt. In de onderstaande opsomming van activiteiten wordt er van uit gegaan dat in deze fase het informatiesysteem volledig wordt gemaakt. Als 
ontwikkelingsactiviteit is op dit punt alleen het ontwikkelen en toepassen van de enquête ten aanzien van de monitoringgegevens opgenomen. Er wordt van uit gegaan dat de methoden die zijn ontwikkeld voor het maken van prognoses en het meten van kwalificatieprofielen na eventuele bijstelling goed functioneren en zich gemakkelijk laten toepassen op een grotere verzameling bedrijuen dan in het personeelregistratiesysteem van de SVZ is onderscheiden. Deze activiteiten zijn derhalve niet opgenomen in de beschrijving van de activiteiten van de derde ontwikkelingsfase.

- Het bijstellen van de toegepaste methoden en technieken op basis van de in de tweede fase opgedane ervaringen.

- Het ontwikkelen van een vragenlijst en het uitvoeren van een enquête onder bedrijven die niet zijn opgenomen in het personeelregistratiesysteem van de SVZ, met betrekking tot gegevens die voor het monitoringdeel van het informatiesysteem van belang zijn (zie hoofdstuk 6). Hierbij zouden de grote bedrijven integraal en de kleine bedrijven via een roterende steekproef kunnen worden benaderd.

- Het in een draaiboek vastleggen van alle procedures die moeten worden gevolgd voor de jaarlijkse actualisering van het monitoringsysteem, de tweejaarlijkse middellange-termijnprognoses en de jaarlijkse (her)meting van telkens een deel van de kwalificatieprofielen die in het informatiesysteem expliciet worden onderscheiden.

- Het adviseren over de organisatorische opzet van de jaarlijkse actualisering, de verdere ontwikkeling en de exploitatie van het informatiesysteem.

- Het ontwikkelen van een meetinstrument voor de technologische veranderingen op de middellange termijn en hun implicaties voor de omvang, de functiestructuur en het kwalificatieprofiel van de werkgelegenheid. Het uittesten van dit instrument en het na eventuele bijstelling integreren ervan in het informatiesysteem onderwijs-arbeidsmarkt.

Het is van belang op te merken dat de jaarlijkse actualisering en het tweejaarlijks maken van prognoses buiten de ontwikkeling van het systeem vallen en derhalve niet in bovenstaande opsomming van activiteiten zijn opgenomen. De toekomstige ervaringen met het informatiesysteem en de in de loop van de tijd verkregen nieuwe inzichten zullen ongetwijfeld aanleiding geven tot verbetering en vernieuwing van het systeem. Het heeft evenwel weinig zin nu reeds vooruit te lopen op de activiteiten die in dat verband eventueel noodzakelijk zouden zijn. Daarom wordt de ontwikkelingsperiode van het 
informatiesysteem hier afgesloten met de beschreven derde fase. Het is evenwel goed te beseffen dat het te ontwikkelen informatiesysteem onderwijsarbeidsmarkt een blijvende voorziening is die permanent moet worden onderhouden en van tijd tot tijd om vernieuwing vraagt.

\subsection{Enkele organisatorische aspecten}

Het ROA zou een groot deel van de taken die in bovengenoemde fasering zijn genoemd zelf kunnen uitvoeren. Voor een aantal taken is het evenwel aan te bevelen gebruik te maken van elders aanwezige expertise. In het bijzonder wordt hierbij gedacht aan het ontwikkelen van een instrument voor het meten van de kwalificatieprofielen van functies, het verstrekken van automatiseringsadviezen aan de SVZ en de ontwikkeling van een gebruiksvriendelijk soft-ware programma voor de presentatie van de informatie in geautomatiseerde vorm. Om de ontwikkeling van het informatiesysteem doelmatig te laten verlopen wordt evenwel voorgesteld dat het ROA een coördinerende rol vervult met betrekking tot de inbreng van de andere participanten in de ontwikkeling van het informatiesysteem.

Benadrukt moet worden dat het voor het welslagen van het project van cruciaal belang is dat de medewerking wordt verkregen van alle in het voorstel genoemde partijen. De participatie van de betrokken bedrijven, het netwerk van sleutelpersonen, de SVZ, met name ten aanzien van de aanpassing van het personeelregistratiesysteem, de betrokken scholen, het COA-Rijndelta, ten aanzien van de RUBS-enquête, het Gewestelijk Arbeidsbureau Rotterdam en vanzelfsprekend ook het Gemeentelijk Havenbedrijf Rotterdam, voor het nemen van initiatieven, het bemiddelen tussen partijen en het geven van informatie en advies, is onontbeerlijk.

Tenslotte kunnen nog enkele opmerkingen worden gemaakt over het latere beheer van het informatiesysteem. Uit de genoemde fasering blijkt duidelijk dat dit pas concreet aan de orde zal komen in de derde ontwikkelingsfase. Het is de vraag of het zinvol is daar nu reeds op vooruit te lopen. In elk geval zal eerst in de tweede ontwikkelingsfase moeten blijken of het systeem inderdaad van de grond komt en blijkt te functioneren. Bovendien is de keuze van de meest geschikte instelling afhankelijk van allerlei beleidsmatige overwegingen die buiten de competentie van dit onderzoek vallen. Wel kan hier worden opgemerkt dat het voor een goed functionerend informatiesysteem verstandig is het beheer in handen te geven van een in de regio gevestigde 
$-48-$

onafhankelijke instelling waar een voldoende professionele basis aanwezig is en die het gezag en vertrouwen geniet van alle betrokken partijen. Deze instelling zal dan voor een aantal uitvoerende taken, met name het houden van enquêtes en het maken van prognoses, diensten kunnen betrekken van derden. 


\section{LITERATUUR}

Bedrijfstak Informatiecentrum (BIC) (1987), Beroepenenquête Grafische Industrie 1986, Amstelveen.

Bochove A. van, A.M. van Eyck (1989), Bijscholing in de Rijndeltaregio, Research voor Beleid, Leiden.

Borsboom, L.J.M. (1988), Aansluitingsproblematiek onderwijs arbeidsmarkt in de Rotterdamse Haven, Hilferink en Croonen/Organisatieadviseurs, Apeldoorn.

Bosch M.R.J., A.J. Doe (1988), Werkgelegenheid in de Rotterdamse haven, Havenbedrijf der Gemeente Rotterdam, Rotterdam.

Centraal Bureau voor de Statistiek, Statistiek voor het beroepsonderwijs 1982/'83 technisch onderwijs, nautisch onderwijs, Voorburg.

Driel van $H_{.}$, De herstrukturering van de Rotterdamse stukgoedsektor, Tijdschrift voor politieke ekonomie, jaargang 11, nr. 4, december 1988.

Elseviers, VSNU en HBO-raad (1988), Elseviers Studie Almanak 1989, Annoventura, Amsterdam.

Gewestelijk Arbeidsbureau Bergen op Zoom (1988), Project Metaal-Electro Zuidwest-Nederland, Rapportage 1988, Bergen op Zoom.

Gianotten, H.J. (1987), Dienstverleners tussen handel en transport, Economisch instituut voor het Midden- en Kleinbedrijf, Zoetermeer.

Grafisch opleidingscentrum, (1987), Beroepensamenstelling en opleidingsbehoeften in de Grafische Industrie 1986-1991, Bedrijfstak Informatie Centrum, Diemen.

Grafisch opleidingscentrum, (1987), Grafisch Onderwijs in perspectief, Bedrijfstak Informatie Centrum, Diemen.

Havenbedrijf der Gemeente Rotterdam (1987), Jaarverslag 1987, Havenbedrijf der Gemeente Rotterdam, Rotterdam.

Heijke, J.A.M., L.H. Klaassen, C.J. Offereins (1975), Naar een arbeidsmarktmode l, Tjeenk Willink, Groningen.

Kamer van Koophandel en Fabrieken voor Rotterdam en de Beneden-Maas (1989), Enquête regionale bedrijfsontwikkeling 1988, Rotterdam.

Kayzel, R., J. van Wel (1985), Veranderingen in de beroepspraktijk van vakmensen en gevolgen voor de beroepsopleidingen, Verslag van een onderzoek, Stichting voor Onderzoek van het Onderwijs, Den Haag.

Martens, A. (1987), Nieuwe gids voor school en beroep 1987-1988, De Toorts 24e editie, Haarlem.

Pedagogisch Centrum Beroepsonderwijs Bedrijfsleven (1983), Handleiding voor beroepenanalyse, PCBB, Den Bosch. 
Provincie Zuid-Holland (1988), Statistiek van vestigingen en werkzame personen in Rijnmond, Provincie Zuid-Holland, afdeling Economische Zaken, bureau Economische Ontwikkeling en Statistiek, Den Haag.

Port of Rotterdam (1985), Koers: 2010, Prognoses van de goederenstromen door de Rijnmondhavens 1990, 2000 en 2010, Rotterdam.

Port of Rotterdam (1985), Koers 2010, Port of Rotterdam, Rotterdam.

SIBAS, Samenwerkende Instellingen t.b.v. beleidsanalytische studies (1986), Transportbegeleidingssysteem in de Rotterdamse haven, sociale gevolgen informatisering, Delft.

Smit E.J. (1988), De CAO-struktuur in de Rotterdamse Haven, Havenbedrijf van de Gemeente Rotterdam, Rotterdam.

Verkuyl, L. (1987), Elseviers Beroepen Almanak, Annoventura, Amsterdam.

Wiel-Bruinsma, W.M. van der, R.M. Zimmermann (1985), Leerstofafstemming haven-school Stichting Vervoer- en Havenopledingen, Rotterdam. 
Bijlage 1

Lijst van geïnterviewde personen:

- Mw. W.M. van der WielBruinsma*

- Dhr.R.M. Zimmermann*

- Dhr. L.F.J. Jansen*

- Dhr. A. Th. van der Gaag

- Dhr. D.M. Vis*

- Mw. D. V. d. Heem*

- Dhr. A.J. Doe*

- Dhr.E.J. Smit

- Dhr. J. Spijker*

- Dhr. N. van Opstelten*

- Dhr. Van Maastrigt

- Dhr. N. van Mourik*

- Mevr. N. Samkalden

- Dhr. P. van Engelen

- Dhr. D.A. Schreuders

- Dhr. N. Verhulst

- Dhr. P. Bosschaart
Haven- en Vervoerschool "Dr. A.J.T. Stakenburg"

Haven- en Vervoerschool "Dr. A.J.T. Stakenburg"

Havenwerkgeversvereniging SVZ

Havenwerkgeversvereniging SVZ

CNV - District Zuid-Holland

Vervoersbond FNV

Gemeentelijk Havenbedrijf Rotterdam

Gemeentelijk Havenbedrijf Rotterdam

Provincie Zuid-Holland

Gewestelijk Arbeidsbureau

Gewestelijk Arbeidsbureau

Kamer van Koophandel en Fabrieken

Kamer van Koophandel en Fabrieken

Gemeente Rotterdam

Gemeente Rotterdam

Europe Container Terminus BV

Gewestelijk Arbeidsbureau Bergen op Zoom

* De met * gemerkte personen hebben zitting in de Begeleidingscommissie 
Bijlage 2

Het goederenstromenmode 1

Het Havenbedrijf van de gemeente Rotterdam beschikt over een model voor het maken van lange termijn prognoses van de ontwikkeling van de goederenstromen via de Rijnmondhavens (de havens van Rotterdam, Schiedam, Vlaardingen, Maassluis en Hoek van Holland). Daarbij wordt uitgegaan van 3 mogelijke ontwikkelingspaden. Variant $A$ gaat ervan uit dat maximaal wordt geprofiteerd van de nieuwste technologieën, hetgeen leidt tot groei. Bij variant $C$ wordt de technologische vooruitgang slechts gebruikt om arbeid te sparen. Veel bedrijfsactiviteiten worden verplaatst naar landen buiten Europa. Het ontwikkelingspad tussen deze twee uitersten, variant $B$, leidt wel tot groei maar die is lager dan bij variant $A$, omdat technologische oplossingen vertraagd worden toegepast als gevolg van de tegenkrachten in de samenleving. Voor het Goederenstromenmodel V (1985) zijn de goederen in 17 groepen ingedeeld. Voor elke goederengroep zijn deelstromen vastgesteld op basis van de landen van herkomst en/of bestemming. Vervolgens is voor elke deelstroom onderzocht door welke factoren zijn ontwikkeling wordt beïnvloed. Om een prognose van de omvang van de goederenstromen te maken, is de toekomstige ontwikkeling van de verklarende variabelen geraamd. De uiteindelijk verkregen prognoses vormen indicaties voor de te verwachten ontwikkelingen op lange termijn (1990, 2000 en 2010).

De concurrentieverhoudingen tussen de Rijnmondhavens en de overige Westeuropese zeehavens zijn beperkt in de structuur van het model verwerkt. Aan hun eventuele effecten voor de prognoses wordt buiten het model apart aandacht besteed. Indien nodig worden de modeluitkomsten nog aangepast. Naast prognoses per goederenstroom (uitgedrukt in mln. tonnen) wordt ook aandacht besteed aan de wijze waarop goederen worden overgeslagen: er wordt een scheiding in stukgoed en massagoed aangebracht en het stukgoed wordt verdeeld in containervervoer, roll-on/roll-off vervoer, lashvervoer, vervoer van overig stukgoed (conventioneel stukgoed en neo-bulk). De effecten van deze "verschijningsvormen" zijn meegenomen in de prognoses. 


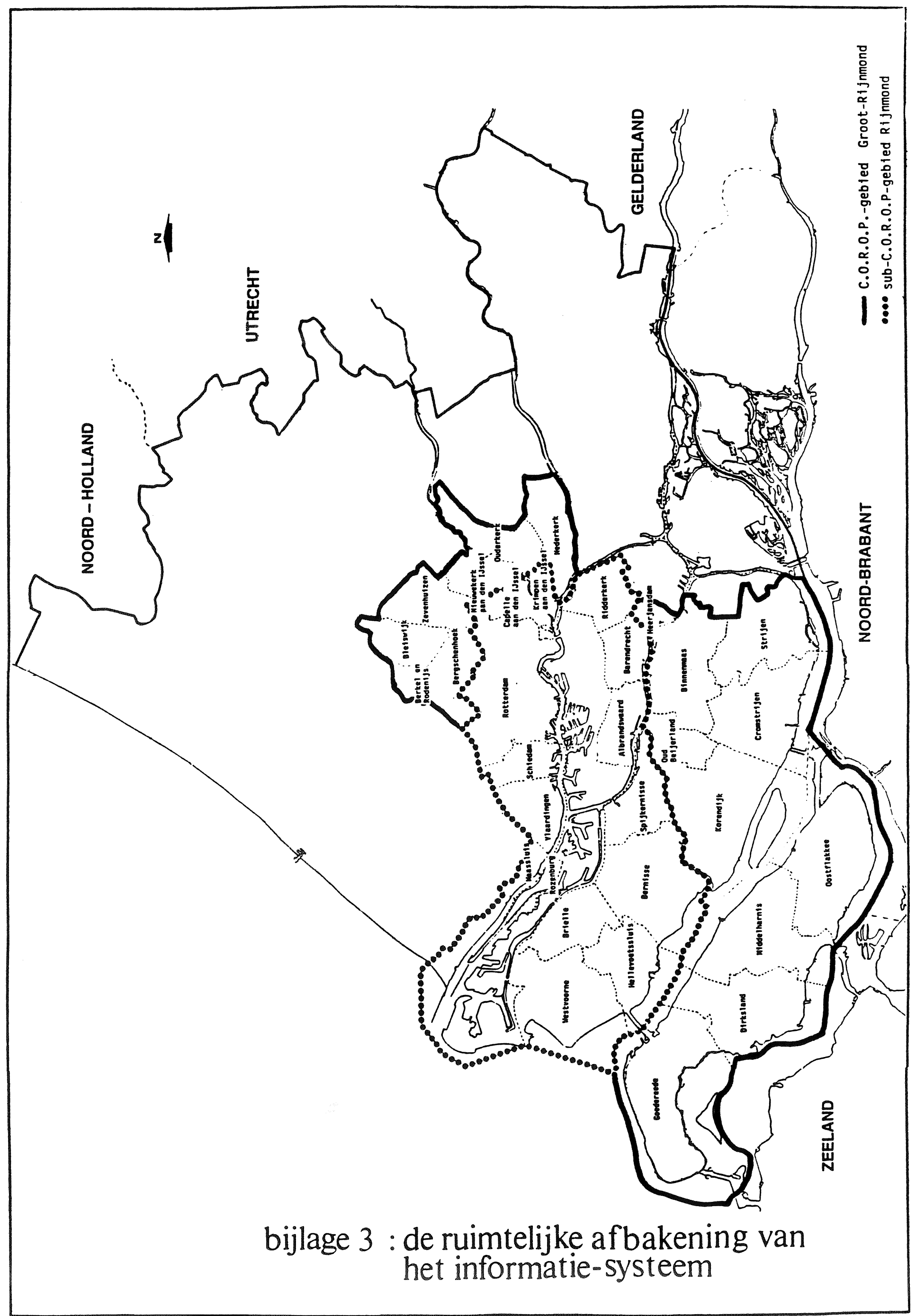


Toelichting bij bijlage 3

De ruimtelijke afbakening van het informatiesysteem

Het voormalig Openbaar Lichaam Rijnmond viel samen met het sub-COROPgebied Rijnmond. Het Sub COROP-gebied Rijnmond vormt een onderdeel van het COROP-gebied Groot-Rijnmond ( $n r .29)$. De volgende gemeenten vallen onder het COROP-gebied Groot-Rijnmond (de onderstreepte gemeenten vallen ook binnen het sub-COROP-gebied Rijnmond):

\begin{tabular}{|c|c|}
\hline Albrandswaard & Barendrecht \\
\hline Bergschenhoek & Berkel en Rodenijs \\
\hline Bernisse & Binnenmaas \\
\hline Bleiswijk & Brielle \\
\hline Capelle a/d IJssel & Cromstrijen \\
\hline Dirksland & Goedereede \\
\hline Heerjansdam & Hellevoetssluis \\
\hline Korendijk & Krimpen a/d IJssel \\
\hline Maassluis & Middelharnis \\
\hline Nederkerk & Nieuwekerk a/d IJssel \\
\hline Oostflakkee & Oud Beijerland \\
\hline Ouderkerk & Ridderkerk \\
\hline Rotterdam & Rozenburg \\
\hline Schiedam & Spijkernisse \\
\hline Strijen & vlaardingen \\
\hline Westvoorne & Zevenhuizen \\
\hline
\end{tabular}


Bijlage 4

Overzicht van de HB-sector-indeling

\begin{tabular}{|c|c|}
\hline $\begin{array}{l}\text { Stuwadoorsbedrijven } \\
\text { Stukgoed: multipurposebedrijven } \\
\text { SHB-pool } \\
\text { Full-containerbedrijven } \\
\text { Ro-ro-stuwadoors } \\
\text { Graan op- en overslagbedrijven } \\
\text { Machinale overslagbedrijven }\end{array}$ & $\begin{array}{l}01000 \\
01100 \\
01200 \\
01300 \\
01400 \\
01500 \\
01600\end{array}$ \\
\hline $\begin{array}{l}\text { Transportbedrijven } \\
\text { Zeescheepvaart } \\
\text { Kleine handelsvaart en grote vaart } \\
\text { Tankvaart } \\
\text { Visserij } \\
\text { Binnenvaart } \\
\text { Tankvaart } \\
\text { Binnenvaartrederijen } \\
\text { Part. Binnenvaartschippers } \\
\text { Binnenvaart verwante bedrijven } \\
\text { Overige transportondernemingen } \\
\text { Spoorwegen } \\
\text { Pijpleidingbedrijven } \\
\text { Wegvervoer }\end{array}$ & $\begin{array}{l}02000 \\
02100 \\
02110 \\
02120 \\
02130 \\
02200 \\
02210 \\
02220 \\
02230 \\
02240 \\
02300 \\
02310 \\
02320 \\
02330\end{array}$ \\
\hline $\begin{array}{l}\text { Opslag- en distributiebedrijven } \\
\text { Vemen en pakhuizen } \\
\text { Tank op- en overslagbedrijven } \\
\text { Tankopslagbedrijven } \\
\text { Tankoverslagbedrijven }\end{array}$ & $\begin{array}{l}03000 \\
03100 \\
03200 \\
03210 \\
03220\end{array}$ \\
\hline $\begin{array}{l}\text { Tussenpersonen } \\
\text { Expediteurs } \\
\text { Cargadoors } \\
\text { Geïntegreerde tussenpersonen }\end{array}$ & $\begin{array}{l}04000 \\
04100 \\
04200 \\
04300\end{array}$ \\
\hline $\begin{array}{l}\text { Hulpdiensten t.b.v. het vervoer } \\
\text { Controlebedrijven } \\
\text { Roeiers } \\
\text { Sjorbedrijven } \\
\text { Reddings-, bergings-, en sleepbedrijven } \\
\text { Reddings-, en bergingsbedrijven } \\
\text { Sleepbedrijven } \\
\text { Verhuurbedrijven transportmiddelen } \\
\text { Containerservice en -verhuurbedrijven } \\
\text { Shipchandlers } \\
\text { Bunkerbedrijven } \\
\text { Bewakings- en beveiligingsdiensten }\end{array}$ & $\begin{array}{l}05000 \\
05100 \\
05200 \\
05300 \\
05400 \\
05410 \\
05420 \\
05500 \\
05600 \\
05700 \\
05800 \\
05900\end{array}$ \\
\hline $\begin{array}{l}\text { Havenindustrie } \\
\text { Aardolieraffinaderijen } \\
\text { Kunstmeststoffenfabrieken } \\
\text { Chemische industrie } \\
\text { Voedingsmiddellenindustrie }\end{array}$ & $\begin{array}{l}06000 \\
06110 \\
06120 \\
06130 \\
06140\end{array}$ \\
\hline
\end{tabular}


$-56-$

Scheepsnieuwbouw en -reparatie $\quad 06200$

Jachten $\quad 06210$

Binnenvaart $\quad 06220$

Off shore $\quad 06230$

Kustvaartuigen $\quad 06240$

Overige zeeschepen $\quad 06250$

Scheepsonderhoud $\quad 06260$

$\begin{array}{ll}\text { Overheid } & 07000\end{array}$

Loods-, sein- en sluiswezen $\quad 07110$

Gemeentelijk Havenbedrijf Rotterdam $\quad 07120$

Gemeentewerken Rotterdam $\quad 07130$

G.E.B.-centrales $\quad 07140$

Rijkswaterstaat $\quad 07150$

Douane $\quad 07160$

Rivierpolitie $\quad 07170$

Inspectie van de Havenarbeid 07180

Onderwijsinstellingen $\quad 07190$

Overige overheid 07200

Overigen $\quad 08000$

Werkgevers- en werknemersorganisaties $\quad 08100$

Overigen $\quad 08200$

Bron: Gemeentelijk Havenbedrijf Rotterdam, 1989. 
Bijlage 5

Vertaling van HB-sector-code naar SBI-code

$\underline{H B-s e c t o r-c o d e}$

Multipurposebedrijven

SHB-pool

Ful1-containerbedrijven

Ro-ro-stuwadoors

Graan op- en overslagbedrijven

Machinale overslagbedrijven

Vemen en pakhuizen

Tank op- en overslagbedrijven

Expediteurs

Cargadoors

Overige tussenpersonen

Controlebedrijven

\section{$\underline{\text { SBI-code }}$}

$7239-7331-7419$

7331

$3722-7331$

$7319-7331$

$2041-7331-7631$

$7331-7629$

$7239-7331-7629-7631$

$7331-7631$

$7239-7311-7319-7321-7331-$

$7419-7429-7621-7629-7631$

$7239-7311-7319-7321-7331$

$7339-7413-7419-7629-7631$

7239 - $7311-7319-7321-7331-$

$7339-7419-7629-7631$

6112 - 7239 - $7331-7339-7621-$

$7622-7629-7631$

Bron: Bosch en Doe, 1988, pp. 38-39. 
Bijlage 6

Aantal vestigingen, aantal werknemers en gemiddelde vestigingsgrootte per HB-sub-sector per 1-5-'87

\begin{tabular}{|c|c|c|c|c|c|c|}
\hline \multirow[t]{2}{*}{ HB-sub-sectoren } & \multicolumn{2}{|c|}{$\begin{array}{ll} & \text { Aantal } \\
& \text { vestigingen } \\
\end{array}$} & \multicolumn{2}{|c|}{$\begin{aligned} & \text { Aantal } \\
& \perp \text { werknemers } \\
&\end{aligned}$} & \multicolumn{2}{|c|}{$\begin{array}{l}\text { Gemiddel de } \\
\text { | } \text { vestigingsgrootte }\end{array}$} \\
\hline & I & & I & & I & \\
\hline \multirow[t]{2}{*}{ Stuwadoorsbedrijven } & 1 & & 1 & & I & \\
\hline & 1 & & 1 & & I & \\
\hline - Stukgoed: multipurpose & 1 & 52 & 1 & 3.004 & I & 58 \\
\hline - SHB - pool & 1 & 1 & I & 2.115 & 1 & 2.115 \\
\hline - Ful1 - containerbedrijven & । & 9 & I & 2.000 & I & 222 \\
\hline - Graan op- en overslagbedrijven & 1 & 3 & 1 & 628 & 1 & 209 \\
\hline \multirow[t]{2}{*}{ - Machinale overslagbedrijven } & 1 & 11 & 1 & 1.675 & I & 152 \\
\hline & । & & 1 & & I & \\
\hline \multirow[t]{2}{*}{ Overslag en distributiebedrijven } & 1 & & I & & I & \\
\hline & 1 & & 1 & & 1 & \\
\hline - Vemen en pakhuizen & 1 & 38 & I & 599 & 1 & 16 \\
\hline \multirow[t]{2}{*}{ - Tank op- en overslagbedrijven } & 1 & 20 & I & 1.513 & | & 76 \\
\hline & 1 & & 1 & & 1 & \\
\hline \multirow[t]{2}{*}{ Tussenpersonen } & I & & 1 & & 1 & \\
\hline & I & & I & & 1 & \\
\hline - Expediteurs & I & 311 & I & 3.059 & 1 & 10 \\
\hline - Cargadoors & 1 & 242 & 1 & 2.784 & । & 11 \\
\hline \multirow[t]{2}{*}{ - Geïntegreerde tussenpersonen } & 1 & 90 & 1 & 2.812 & 1 & 29 \\
\hline & I & & I & & 1 & \\
\hline \multirow[t]{2}{*}{ Hulpdiensten t.b.v. het vervoer } & I & & 1 & & I & \\
\hline & 1 & & 1 & & I & \\
\hline \multirow[t]{3}{*}{ - Controlebedrijven } & I & 99 & 1 & 1.292 & । & 13 \\
\hline & I & & I & & 1 & \\
\hline & 1 & & 1 & & 1 & \\
\hline Totaal & 1 & 876 & 1 & 21.481 & 1 & \\
\hline
\end{tabular}

Bron: Gemeentelijk Havenbedrijf Rotterdam, 1989. 
Bijlage 7 Overzicht van beroepen/functie-indelingen

Beroepenclassificatie (CBS):

Het CBS heeft een standaard beroepenclassificatie samengesteld die geënt is op internationale normen. De volgende beroepen (4 digit) uit de beroepenclassificatie zijn relevant voor de Rotterdamse haven:

359 Overig toezichthoudend-en leidinggevend personee 1

- 3592 Ladingmeester (transport- en opslagbedrijf)

- 3599 Controleurs en toezichthoudend personeel transportdiensten (incl. specialisatie onbekend)

391 Employes goederenexpeditie, magazijn en voorraadadministratie ed

- 3912 administratief employe expeditie en bevrachting

- 3913 voorraadadministrateur

- 3914 magazijnbediende

- 3915 weger, meter

845 Machinereparateurs, onderhoudsmonteurs

- 8457 Overige gespecialiseerde machinereparateurs, algemeen onderhoudsmonteur bedrijfsinstallaties ed (excl. electrotechnisch)

971 Laders, lossers. pakhuisknechts, magazijnknechts, inpakkers ed

- 9712 Lader en losser (in havenbedrijf)

973 Kraan- en hijmachinisten

- 9732 Kraanmachinist, kraandrijver (geen grondverzet)

- 9739 Overige kraan- en hijsmachinisten

979 Heftruckdrijvers ea bedieners van interne transportmiddelen ed

- 9792 Heftruckdrijvers ea motordrijvers intern transport

985 Chauffeurs en trambestuurders

- 9855 Vrachtwagenchauffeur, bestelautochauffeur

\section{Voordelen:}

a. De Beroepenclassificatie van het $C B S$ is een veel toegepaste classificatie. Ook het RUBS-project gebruikt deze classificatie.

Nadelen:

a. De beroepen die in de haven voorkomen zijn voor een deel zeer specifiek voor de haven. Enkele beroepen, vooral in de technisch-administratieve sfeer, alsmede in de procescontrole zijn om deze reden moeilijk in de CBS-beroepenclassificatie te passen.

b. De link tussen opleiding(-smodules) en beroep is moeilijk te leggen. Dit geldt vooral voor de administratieve beroepen. 
Beroepenindeling ARBI:

In de ARBI-beroepenindeling, samengesteld door ARBVO, worden enkele beroepen onderscheiden die in de haven voorkomen. De gegevens over de werkeloosheid zijn volgens deze indeling geclassificeerd. De nadelen die met betrekking tot de CBS-beroepenindeling genoemd zijn, gelden echter ook voor deze indeling. Indien dan toch voor een "erkende" indeling wordt gekozen, geniet de CBS-indeling de voorkeur, daar deze in tegenstelling tot de indeling van ARBVO in zowel de Enquête Beroepsbevolking als in het RUBS-project wordt gebruikt. Op de bijzonderheden van de ARBI-indeling wordt gezien de genoemde beperkingen niet nader ingegaan.

\section{Functie-indeling Van der Wiel en Zimmermann}

Op basis van een lijst met alle veel voorkomende functies in de haven (in totaal 52) zijn Van der Wiel en Zimmermann gekomen tot een indeling in 7 functiegroepen:

I Operationele functies

- Handfuncties

- Bedieners kleine apparaten

- Bedieners grote apparaten

- Kwaliteitscontrole

- Procescontrole

II Administratieve functies

- Cargadoorsfuncties

- Expeditiefuncties

Deze indeling is tot stand gekomen door een aantal sterk verwante functies te clusteren, waarvoor de benodigde opleidingen (cursorisch onderwijs) toch in grote lijnen identiek zijn. De clustering in de operationele functies sluit ook aan bij de interne mobiliteit (functie-mobiliteit) die te constateren is in deze sector. Vaak begint men als handwerker en klimt dan eventueel op -na gebleken geschiktheid- op tot bediener van een klein apparaat en vervolgens tot bediener van een groot apparaat. Hetzelfde geldt voor de controleurs: ook zij zijn begonnen als handwerker (Van der Wiel en Zimmermann, 1985, p. 22).

Volledigheidshalve dient te worden opgemerkt dat de hogere functies niet onder deze indeling vallen. Door de categorie staffuncties aan de functieindeling toe te voegen, kunnen ook de hogere functies ondergebracht worden. In een door Van der Wiel en Zimmermann opgesteld overzicht van cursussen 
ingedeeld naar niveau en aard van de werkzaamheden waarop de cursussen gericht zijn, worden ook de categorieën onderhoud en bewaking onderscheiden. Een toevoeging van de categorie onderhoudsfuncties aan de functie-indeling zou een nuttige uitbreiding kunnen zijn.

\section{Voordelen:}

a. Deze functie-indeling sluit aan bij de vaardigheden die voor de uitoefening van verschillende functies vereist zijn. Veel (praktijkgerichte) opleidingsmodules kunnen worden gegroepeerd op basis van de functies waarvoor ze opleiden. $O p$ deze manier is een beperkte koppeling mogelijk tussen scholing en functie.

b. Deze functie-indeling is gebaseerd op functies die in de haven voorkomen. Om deze reden dekt de functie-indeling in grote mate het scala aan functies dat in de haven voorkomt.

Nade 1en:

a. De koppeling met de beroepenindeling van het CBS is voor enkele functiegroepen moeilijk te maken. Met name het onderscheid tussen goederen- en procescontrole is moeilijk aan te brengen in de CBSclassificatie. Om deze reden kan de vertaling van CBS-beroepen codes naar een functiegroep en omgekeerd, problemen opleveren. Dit is een groot nadeel omdat zowel de uitkomsten van het RUBS-project als de landelijke beroepen-prognoses van het ROA gecodeerd zijn volgens de beroepenclassificatie van het CBS.

\section{Functie-Indeling Personeel registratiesysteem SVZ:}

Deze functie-indeling is gebaseerd op de functies die in de CAO's omschreven staan. Per sector worden een aantal functies onderscheiden (zie bijlage 8 ). Een aantal van deze functies zijn echter niet specifiek voor de haven. Functies als: portier/bewaking, varend personeel en administratief medewerker kunnen daarom buiten beschouwing worden gelaten. 
Voordelen:

a. De functie-indeling van de SVZ sluit aan bij de in de haven bekende CAO-functies.

b. In het personeelregistratiesysteem - een enorm belangrijke bronwordt deze indeling gehanteerd.

\section{Nadelen:}

a. Per sector worden verschillende functienamen van vergelijkbare functies onderscheiden. Hierdoor is het totaal aantal functies onnodig groot.

b. De functie-indeling heeft alleen betrekking op personeel vallend onder een door de S.V.Z, afgesloten CAO's. Niet alle functies vallen echter onder deze CAO's. Voor beambten bijvoorbeeld, wordt vaak geen CAO afgesloten. Bovendien zijn voor enkele sectoren binnen de haven, met name de expediteurs- en cargadoorssector, geen CAO's afgesloten. De functies die binnen deze sectoren voorkomen vallen om bovengenoemde reden buiten de functie-indeling. Uit de notitie van het Gemeentelijk Havenbedrijf Rotterdam "De CAO-structuur in de Rotterdamse haven" (Smit, 1988, p.15) blijkt dat de dekking van de CA0-structuur waarbij de SVZ contract-partner is, varieert van 0 procent (cargadoors en olieopslag) tot 85 procent (multi-purpose overslag in combinatie met veem-en pakhuizen). In de overslagsector is dekking van de CAOstructuur hoog (59-85 procent), in de controlesector daarentegen laag (35 procent) en in de intermediaire sector zeer laag (0-7 procent). Hierbij dient te worden opgemerkt dat de indeling van bedrijven in sectoren die gehanteerd wordt door het Gemeentelijk Havenbedrijf niet geheel overeenkomt met de indeling van de SVZ. In de toekomst zal het aantal CAO's waarbij de SVZ contractpartner is waarschijnlijk eerder af- dan toenemen. $\mathrm{Er}$ is namelijk een verschuiving waarneembaar in de richting van bedrijfs-CAO's ten koste van sector-CAO's. Het is de vraag of de SVZ ook bij deze bedrijfs-CAO's contractpartner zal zijn. 
Bijlage 8

Functie-indeling personeelregistratiesysteem SVZ en de relatie tussen SVZ-code en CBS-code

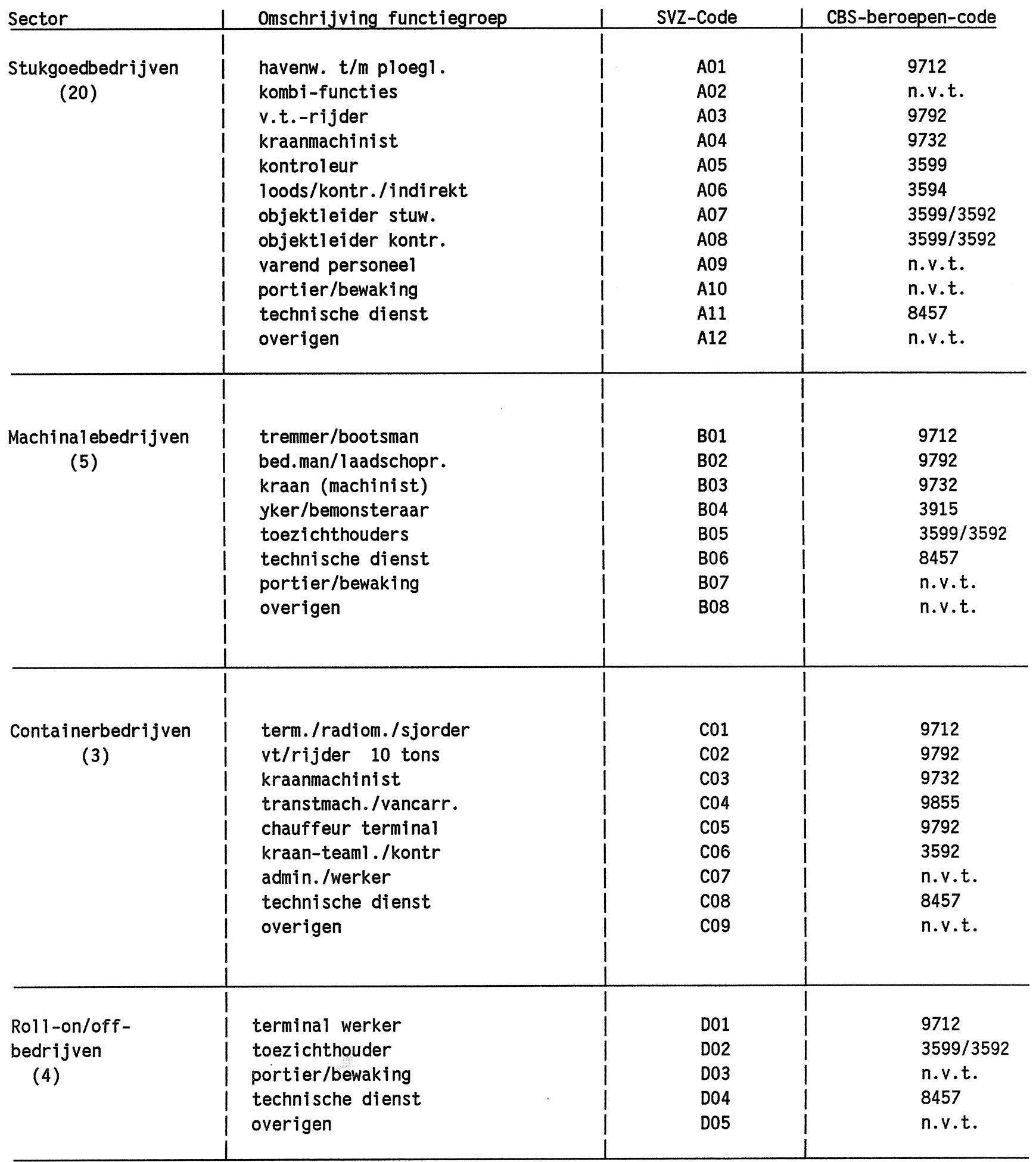




\begin{tabular}{|c|c|c|c|}
\hline $\begin{array}{l}\text { Graanbedrijven } \\
\text { (4) }\end{array}$ & $\begin{array}{l}\text { tremmer } \\
\text { operator } \\
\text { baas/chef } \\
\text { technische dienst } \\
\text { overigen }\end{array}$ & $\begin{array}{l}\text { E01 } \\
\text { E02 } \\
\text { E03 } \\
\text { E04 } \\
\text { E05 }\end{array}$ & $\begin{array}{l}9712 \\
---- \\
3592 \\
8457 \\
\text { n.v.t. }\end{array}$ \\
\hline $\begin{array}{l}\text { Controle- en } \\
\text { Expeditiebedrijven } \\
\text { (70) }\end{array}$ & $\begin{array}{l}\text { expedi ti ewerker } \\
\text { kombifunkties } \\
\text { chauffeurs } \\
\text { kontrol eurs } \\
\text { objectleiders } \\
\text { overigen }\end{array}$ & $\begin{array}{l}\text { G01 } \\
\text { G02 } \\
\text { G03 } \\
\text { G04 } \\
\text { G05 } \\
\text { G06 }\end{array}$ & $\begin{array}{l}9714 \\
\text { n.v.t } \\
9855 \\
3599 \\
3599 \\
\text { n.v.t. }\end{array}$ \\
\hline $\begin{array}{l}\text { Aanverwante bedrijuen } \\
\text { (18) }\end{array}$ & $\begin{array}{l}\text { havenw. } t / m \text { ploegl. } \\
\text { v.t.-rijder } \\
\text { kraanmachinist } \\
\text { kontroleur } \\
\text { loodsadministrateur } \\
\text { objektleider stuwad. } \\
\text { objektleider kontrol. } \\
\text { varend personeel } \\
\text { portier/bewaking } \\
\text { chauffeur } \\
\text { technische dienst } \\
\text { overigen }\end{array}$ & $\begin{array}{l}\text { H01 } \\
\text { H02 } \\
\text { H03 } \\
\text { H04 } \\
\text { H05 } \\
\text { H06 } \\
\text { H07 } \\
\text { H08 } \\
\text { H09 } \\
\text { H10 } \\
\text { H11 } \\
\text { H12 }\end{array}$ & $\begin{array}{l}9712 \\
9792 \\
9732 \\
3599 \\
3913 \\
9712 \\
3599 \\
\text { n.v.t } \\
\text { n.v.t. } \\
9855 \\
8457 \\
\text { n.v.t. }\end{array}$ \\
\hline $\begin{array}{l}\text { SHB } \\
\text { (1) }\end{array}$ & $\begin{array}{l}\text { havenw. t/m ploegl. } \\
\text { kombi-functies } \\
\text { v.t.-rijder } \\
\text { kraanmachinist } \\
\text { kontroleur } \\
\text { overigen } \\
\text { multi-sectorpool }\end{array}$ & $\begin{array}{l}\text { S01 } \\
\text { S02 } \\
\text { S03 } \\
\text { S04 } \\
\text { S05 } \\
\text { S06 } \\
\text { U01 }\end{array}$ & $\begin{array}{l}9712 \\
\text { n.v.t. } \\
9792 \\
9732 \\
3599 \\
\text { n.v.t. } \\
\text { n.v.t. }\end{array}$ \\
\hline
\end{tabular}

Bron: Scheepvaart Vereniging Zuid, Centraal Personeels Bureau, 1989. Centraal Bureau voor de Statistiek, 1985. 
Bijlage 9

Lijst van telefonisch benaderde opleidingsinstituten

- HVS "Prof Rutten" (dhr. Maagdenberg);

- HVS "Jan Backx" (dhr. Vreeswijk);

- HVS "Dr. A.J.T. Stakenburg" (dhr. Zimmermann);

- Hoger Economische School (dhr. Van Gent);

- Hoger Nautisch Onderwijs Rotterdam (dhr. Sterk);

- Hoger Nautisch Onderwijs Maritiem Instituut "De Ruyter" (dhr. Van de Heyde);

- Stichting ter bevordering van het Leerlingwezen in het Haven- en Vervoerbedrijf in Nederland (dhr. Vreeswijk);

- MEAO "De Lijnbaan" (logistieke richting) (dhr. De Reus);

- Vervoersacademie Venio;

- Nationale Vervoersacademie Tilburg;

- Erasmus Universiteit (dhr. Blauwens). 
Bijlage 10

Cursussen HVS "Dr. A.J.T. Stakenburg"

BBO - opleidingen voor deelcertificaten:

- Primair: - Havenwerker stukgoedbedrijf veerdienstbedrijf graanbedrijf machinaalbedrijf tankopslagbedrijf containerbedrijf

- Vorktruckrijder controlebedrijf

- Basiscursus informatica

- Basiscursus gevaarlijke stoffen en beschermingsmiddelen

- Secundair: - Controle granen

- Controleur vloeibare lading

- IJkopnemer

- Bedieningsvakman tankopslagbedrijven

- Laadschoprijder/ bulldozerrijder

- Trekkerchauffeur

- Bedieningsman hijswerktuigen

- Bedieningsman scheepsgerei/scheepskraan

- Bootsman machinaalbedrijf

- Operator graanoverslagbedrijf

- Persluchtmaskerdrager

- Informatica

Niet gesubsidieerde opleidingen:

- standaardpakketten met een open inschrijving, zoals:

- Oriëntatie op de bedrijfstak

- Engels

- Duits

- Algemene ontwikkeling

- Kabelgast

- Chemie

- Veiligheid voor hoger en middenkader

- Cargadoor, in samenwerking met de Vereniging van Rotterdamse Cargadoors

- Expediteur, in samenwerking met de Vereniging van Expediteurs

- Douanewetgeving

- Lager kader

- Middle management in de logistiek

- Havenapplicatiedagen

- cursussen "op verzoek":

- inhoudelijke combinaties van delen uit bovenstaande cursussen, of bestaande cursussen die worden uitgebreid met onderwerpen die door het bedrijf gewenst worden

Bron: Haven en Vervoerschool "Dr. A.J.T. Stakenburg", 1989. 
Bijlage 11 Overzicht van het onderwijs aanbod

Het dagonderwijs:

I Lager Beroeps Onderwijs (LBO)

- Instituut: HVS "Prof Rutten"

Richting: Operationeel (diploma "Maat")

SOI-code: $\quad 34150$

Richting: Technisch-administratief (diploma "Junior")

SOI-code: $\quad 34350$

Opleidingsduur: $\quad 4$ jaar

- Instituut: HVS "Jan Backx"

Richting: Operationeel (diploma "Maat")

SOI-code: $\quad 34150$

Richting: Technisch-administratief (diploma "Junior")

SOI-code: $\quad 34350$

Opleidingsduur: $\quad 4$ jaar

II Middelbaar Beroeps Onderwijs (MBO)

- Instituut: HVS "Jan Backx"

Richting: Technisch-administratief

SOI-code: $\quad 44350$

Richting: Operationeel

SOI-code: $\quad 44150$

Opleidingsduur: $\quad 4$ jaar

II Hoger Beroeps Onderwijs (HBO)

- Instituut: Hoger Economische School (HES)

Richting: Haven-, vervoer-en logistiekmanagement

SOI-code: $\quad 54180$

Opleidingsduur: $\quad 4$ jaar

- Instituut: Hoger Nautisch Onderwijs Rotterdam

Richting: Maritieme Bedrijfsvoering

SOI-code: niet bekend (RUBS-code: 522016)

Opleidingsduur: $\quad 4$ jaar

- Instituut: Hoger Nautisch Onderwijs

Richting: Opleiding havenbedrijfskunde

SOI-code: niet bekend (RUBS-code: 522016)

Opleidingsduur: $\quad 4$ jaar

Het leerlingwezen:

I Primair Leerlingstelsel

- Instituut:

Richting:

SOI-code:

HVS "Prof Rutten"

Operationeel Medewerker (diploma: "Gezel")

44150 
$-68-$

Richting: $\quad$ Werktuigkundig Monteur (WTM)

SOI-code: niet bekend (evt. 44250)

Opleidingsduur: $\quad 2$ jaar (m.u.v. werktuigkundig monteur: 3 jaar)

- Instituut: HVS "Jan Backx"

Richting: Technisch-administratief Medewerker (diploma

SOI-code: $\quad 44350$

Opleidingsduur: $\quad 2$ jaar

- Instituut: Streekschool Amsterdam

Richting: Operationeel

SOI-code: $\quad 44150$

Opleidingsduur: $\quad 2$ jaar

II Voortgezet Leerlingstelsel

- Instituut:

Richting:

SOI-code:

Richting

SOI-code:

HVS "Prof Rutten"

Gevorderd Operationeel Medewerker (GOM)

Opleidingsduur:

niet bekend (evt. 44150)

Vervoer gevaarlijke stoffen

niet bekend

1 jaar

- Instituut:

HVS "Jan Backx"

Richting:

Assistent-expediteur

SOI-code:

niet bekend (evt. 44350)

Richting:

Assistent-cargadoor

SOI-code:

niet bekend (evt. 44350)

Opleidingsduur: 1 jaar

- Instituut:

Streekschool Amsterdam

Richting:

Operationeel

SOI-code:

niet bekend (evt. 44150)

Opleidingsduur:

1 jaar 
Bijlage 12

Overzicht van de relevante beroepen van de ARBI-indeling

ARBI-beroepenindeling:

- 036701 Onderhoudsmonteur (machines)

1311 Chauffeurs

- 131113 Chauffeur (bijzonder goederenvervoer)

- 131114 Chauffeur (buitenlands goederenvervoer)

- 131120 Chauffeur (geregeld goederenvervoer)

- 131121 Chauffeur (lokaal goederenvervoer)

- 131123 Chauffeur (tankwagen)

- 131129 Chauffeur (kraanwagen)

1334 Stuwadoors

- 133401 Stuwadoor

- 133402 Hoofdbaas

1335 Havencontroleurs

- 133501 Controlebaas

- 133502 Controleur (havenbedrijf)

- 133503 Scheepsweger

- 133504 Weger (elevator)

- 133505 Scheepsmeter (scheepslading)

- 133506 IJker (scheepslading)

- 133507 Teller

1336 Havenwerkers

- 133601 Botenbaas

- 133602 Ploegleider

- 133603 Bootsman (havenbedrijf)

- 133606 Stuwer (dek)

- 133608 Havenwerker

- 133609 Tremmer (havenbedrijf)

- 133612 Kabelgast (havenbedrijf)

1344 Cargadoors

- 134401 Cargadoor

- 134402 Chartering-clerk

- 134403 Declarant

- 134404 Waterklerk

- 134405 Runner (havenbedrijf)

1345 Transportpersonee 1

- 134501 Expediteur (internationaal)

- 134502 Tarifeur

- 134505 Expediteur (binnenland)

1346 Expeditiepersonee 1

- 134606 Expeditieknecht (expeditie-afdeling) 
1401 Leidinggevend personee 1

- 140101 Directeur (algemeen)

- 140102 Bedrijfsleider (algemeen)

- 140103 Afdelingsleider (algemeen)

- 140104 Baas (algemeen)

- 140105 Onderbaas (algemeen)

- 140106 Projectleider (algemeen)

- 140107 Manager (algemeen)

1410 Transportpersoneel (intern transport)

- 141001 Heftruckchauffeur

- 141002 Transporteerder (intern transport)

- 141003 Sjouwer (algemeen) 
Bijlage 13

Registraties van werkgelegenheidsgegevens

Tot registraties van werkgelegenheidsgegevens behoren de Statistiek Werkzame Personen (SWP), het Bedrijven en Instellingen Register Zuid-Holland (BIR), de Enquête Regionale Bedrijfsontwikkeling (ERBO), het personeelregistratiesysteem van de SVZ. Het personeelregistratiesysteem van de SVZ is reeds in hoofdstuk 6 aan bod gekomen.

Voor de Statistiek Werkzame Personen van het CBS worden ondernemingen met 10 of meer werknemers integraal benaderd en ondernemingen met minder dan 10 werknemers op steekproefbasis. De steekproef wordt getrokken uit het Algemeen Bedrijfsregister van het CBS. In de jaarlijkse publikaties zijn de verdelingen naar provincie en COROP-gebied opgenomen. Het is mogelijk gegevens op het niveau van gemeente en GAB-rayon te krijgen. Er wordt in deze statistiek per bedrijfstak/klasse informatie gegeven over het aantal werkzame personen, het geslacht en de leeftijd van de werknemers. De indeling van de bedrijfseenheden naar economische activiteit is volgens de SBI (2 digit).

Het Bedrijven- en Instellingenregister Rijnmond (BIR) wordt sinds 1976 bijgehouden door het Openbaar Lichaam Rijnmond en sinds 1986 (als onderdeel van het Bedrijven Register Zuid-Holland) door de provincie Zuid-Holland. Het BIR heeft betrekking op alle vestigingen van bedrijven en instellingen in het Rijnmondgebied. Jaarlijks (rond 1 mei) worden deze bedrijven en instellingen schriftelijk benaderd voor een werkgelegenheidsenquête. De enquêtegegevens worden in een geautomatiseerd bestand opgeslagen. Naast aantallen werkzame personen zijn in dit bestand gegevens opgenomen over het geslacht, de verdeling tussen full-en parttimers en de leeftijdsopbouw van de werkzame personen, evenals aantallen openstaande vacatures en aantallen nieuw in dienst genomen personeelsleden. Het is mogelijk gegevens van verschillende jaren te raadplegen. Definities die in de BIR-enquête en de daarop gebaseerde statistieken zijn gehanteerd sluiten ten dele aan bij de gangbare definities van het CBS. Een verschil in de definiëring van "werkzame personen" is dat het BIR in principe alle personen telt, die 15 uren of meer per week werkzaam zijn in of vanuit een instelling of bedrijf en het CBS zich in de SWP beperkt tot personen die in loondienst werkzaam zijn. De door de bedrijven opgegeven omschrijving van de economische 
activiteiten wordt volgens de SBI van het CBS 4-cijferig gecodeerd. Resultaten van de enquête worden weergegeven in de "Statistiek van Vestigingen en Werkzame Personen". Deze statistiek is gesplitst in een gedeelte standstatistiek en een gedeelte stroomstatistiek. Beide onderdelen bevatten een serie tabellen over het gehele Rijnmondgebied en per Rijnmondgemeente. De standstatistiek gat in op de bedrijuigheid en de werkgelegenheidssituatie per $1 \mathrm{mei}$. De stroomstatistiek geeft inzicht in de dynamiek van het vestigingenbestand en de daarmee gepaard gaande werkgelegenheidsontwikkeling tussen de opeenvolgende jaren. Voor het merendeel van de gegevens geldt dat gedetailleerde uitsplitsingen voorhanden zijn, bijvoorbeeld naar bedrijfssubgroepen of op buurtniveau. Het Havenbedrijf der gemeente Rotterdam krijgt jaarlijks de gegevens van de BIR-enquête op floppy ter beschikking, selecteert de havenbedrijven hieruit, en classificeert deze bedrijuen volgens de HB-sectorcode.

De Enquête Regionale Bedrijfsontwikkeling (ERBO) wordt sinds 1973 jaarlijks uitgevoerd door de Kamer van Koophandel en Fabrieken voor Rotterdam en de Beneden-Maas, en vindt plaats op basis van het Handelsregister. In dit register staan alle ondernemingen met een winstoogmerk ingeschreven, exclusief de zogenaamde "vrije beroepen", de meeste landbouwbedrijven en de straathandel (indien hoofdberoep). De kwartaire sector staat dus niet ingeschreven. Alle bedrijven in het Kamerdistrict Rijnmond met 50 of meer werkzame personen krijgen een enquêteformulier toegezonden. Uit de bedrijven met minder dan 50 werkzame personen wordt een steekproef getrokken. De enquêtegegevens betreffen de omzet en de export, het netto bedrijfsresultaat en het rendement, de investeringen en de werkgelegenheid, en de toekomstverwachtingen voor het komende jaar van de ondernemers. De ERBOgegevens zijn alleen op bedrijfstakniveau (SBI 2-digit) toegankelijk voor derden. 
Ten behoeve van het Centraal Personeelsbureau SVZ en de Stichting Pensioenfonds voor de Vervoer-en Havenbedrijven.

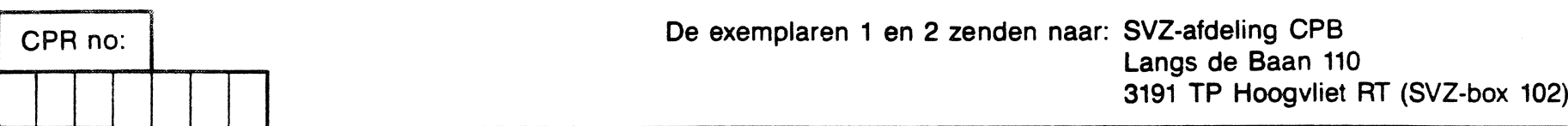

\section{Betreft: $\square$ AANMELDING $\square$ MUTATIE}

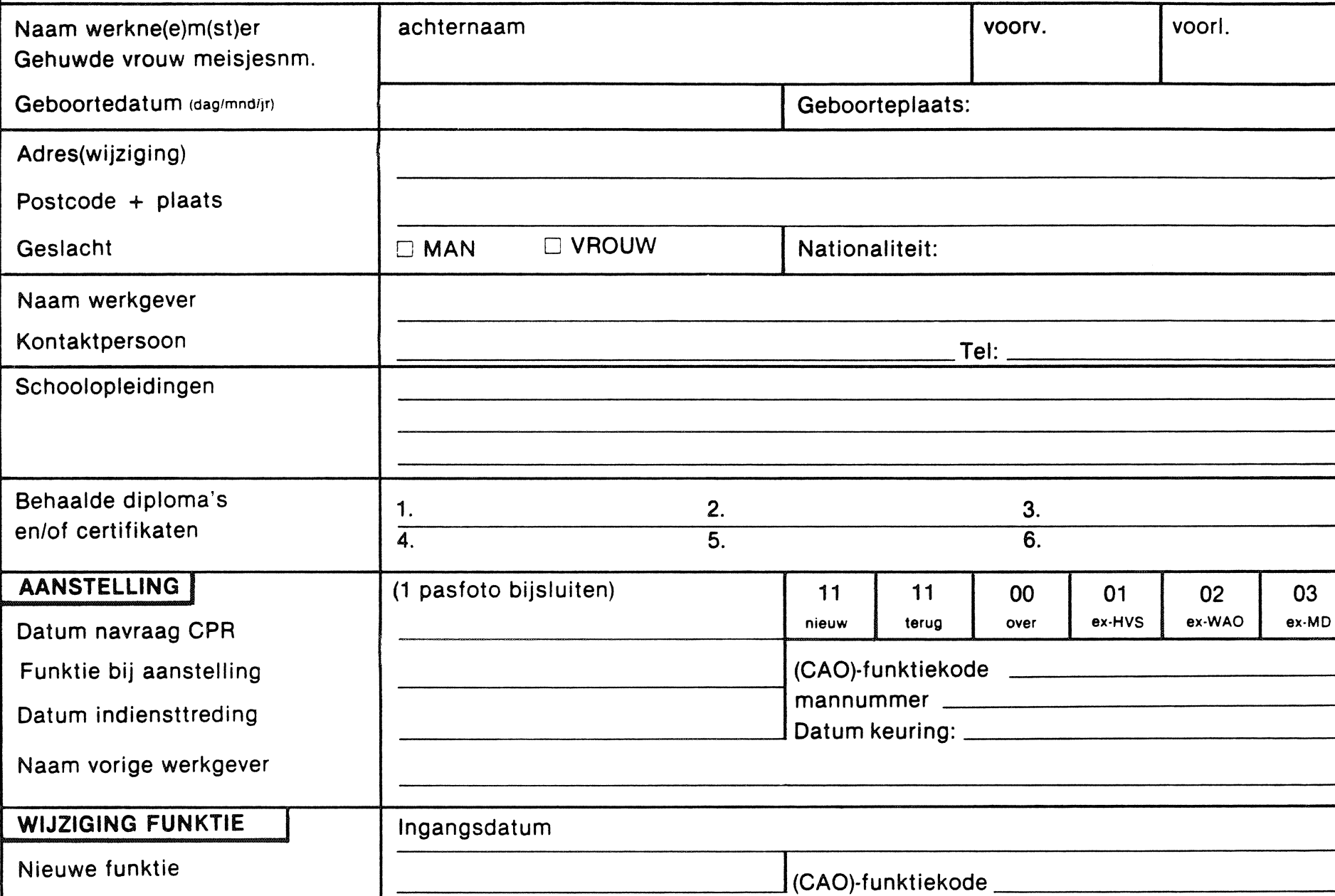

\section{ONTSLAG}

Laatste dag dienstverband

Reden ontslag

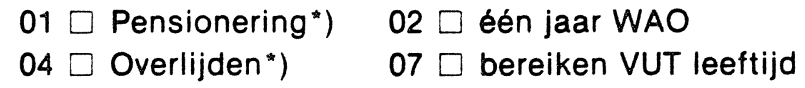

(SVZ-legitimatiebewijs bijsluiten)

Naam nieuwe werkgever

ONDERSTAANDE GEGEVENS ZIJN ALLEEN BESTEMD VOOR HET PENSIOENFONDS

\begin{tabular}{|c|c|c|}
\hline GEGEVENS ECHTGENO(O)T(E) & \multirow[t]{2}{*}{ achternaam } & \multirow[t]{2}{*}{ voorv. } \\
\hline Naam (eigen naam) & & \\
\hline $\begin{array}{l}\text { Geboortedatum (dag/mnd/jr) } \\
\text { Datum huwelijk (dag/mnd/jr) }\end{array}$ & $\begin{array}{l}\text { Geboorteplaats: } \\
\text { datum scheiding }\end{array}$ & datum overlijden \\
\hline
\end{tabular}

Betreft het hier een volledig dienstverband?: $\square$ JA $\square$ NEE $\square \ldots$ _ parttime

\section{WAO}

Ingangs/wijzigingsdatum AAW/WAO-uitkering:

AAW/WAO-klasse $\square 1 / 2 / 3 \square 4 / 5 \square 6 / 7 \square$ geen

Uitkering gecedeerd aan werkgever: $\square$ JA $\square$ NEE

Laatst overeengekomen vast loon op jaarbasis $f$

(alleen invullen bij ingang AAW/WAO klasse 4, 5, 6 of 7) 
8 a. Heb je een betaalde baan gehad sinds je van school bent?

b. Zo ja, hoeveel maanden heb je in totaal gewerkt?

maanden:

Ga door met vraag 16

De opleiding die je nu volgt

Voor degenen die een full-time dagopleiding volgen:

9 a. Welke opleiding volg je op dit moment? (bijvoorbeeld: HAVO, KMBO, MTS, HTS, HBO-J)

b. Welke vakrichting, afdeling of specialisatie doe je binnen deze opleiding?

(bijvoorbeeld: Bouwkunde, Bestuurskunde, Jeugdwelzijnswerk)

Ga door met vraag 16

Voor degenen die een opleiding in het leerlingwezen (streekschool e.d.) of een in-service opleiding volgen:

10 a. Wat voor opleiding volg je op dit moment?

(bijvoorbeeld: automonteur, installatietechniek, ziekenverzorgende, A-verpleegkundige)

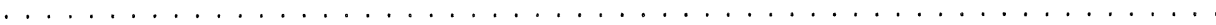

b. Naam leerlingstelsel:

(ECABO, VAM, SOM (metaal), VEV (electro), OVDB, Kappers, Horeca en dergelijke)

c. Heb je naast deze opleiding een betaalde baan?

nee $\longrightarrow$ Ga door met vraag 16

ja Ga door met vraag 11

Je huidige werk en beroep

11 a. Werk je in loondienst?

nee

ja

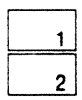

b. Wat voor aanstelling heb je?

vaste aanstelling

tijoliijke aanstelling

werk yoor uitzendbureau

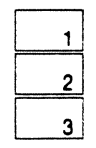

c. Hoeveel uur per week werk je meestal?

minder dan 20 uur

20 tot 32 uur

meer dan 32 uur

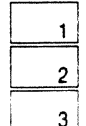


12 a. Hoe ben je aan dit werk gekomen?

via het Arbeidsbureau (één antwoord aankruisen)

via familie of kennissen

via een advertentie in de krant via een advertentie in een winkel e.d.

via een uitzendbureau

via vakantiewerk/bijbaantje

door de stage/via de school

zelf aan de werkgever om werk gevraagd

voor mijzelf begonnen

anders:

b. Hoe snel heb je werk gevonden

toen je vorig jaar van school ging?

meteen

na 1 - 3 maanden

na 4 - 6 maanden

na meer dan 6 maanden

13 a. Hoe heet het beroep of de functie die je uitoefent?

(bijvoorbeeld: secretaresse, tuinder, groepsleider, bouwkundig tekenaar, verkoopster)

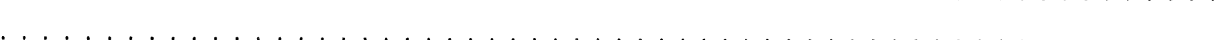

b. Wat zijn je voornaamste werkzaamheden?

(bijvoorbeeld: technisch tekenen, veeverzorging, typen, boekhouden)

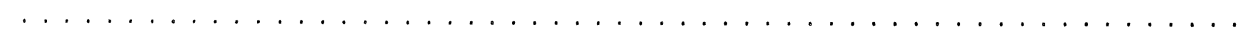

c. Op wat voor afdeling werk je?

(bijvoorbeeld: administratie, montagehal, magazijn, receptie, operatiekamer)

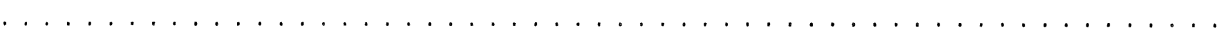

d. Geef je leiding aan ander personeel?

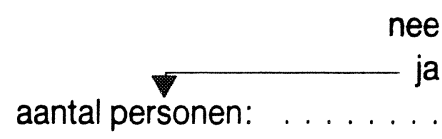

aantal personen. . . . . . . . .

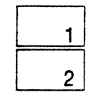

$14 \mathrm{a}$. Bij wat voor bedrijf of instelling werk je?

(bijvoorbeeld: machinefabriek, constructiewerkplaats, kledingwinkel, ziekenhuis)

b. Hoeveel mensen werken er ongeveer bij het bedrijf?

$$
\begin{array}{r}
\text { minder dan } 10 \\
10 \text { tot } 50 \\
50 \text { tot } 100 \\
\text { meer dan } 100 \\
\text { weet ik niet }
\end{array}
$$

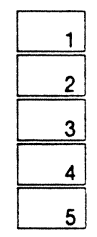

c. In welke plaats werk je?

15. Hoeveel verdien je ongeveer notto ('schoon') per maand? 
$16 \mathrm{a}$. Heb je de afgelopen 4 weken naar (ander) werk gezocht?

b. Zo ja, hoe heb je de afgelopen 4 weken naar werk gezocht?

(LET OP: meer antwoorden mogelijk)

via het Arbeidsbureau

via familie of kennissen

via advertenties in de krant

via advertenties in winkels e.d.

via een uitzendbureau

via de stage/school

zelf aan een werkgever om werk gevraagd

anders:

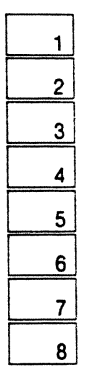

c. Sta je ingeschreven bij het Arbeidsbureau?

nee

ja

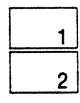

17 a. Volg je een (nog een andere) cursus, training of part-time opleiding?

nee

b. Welke?

\section{De opleiding achteraf bezien}

18. Hieronder noemen we een aantal zaken. Geef aan of daar in de opleiding van vorig jaar (1987/88 dus) voldoende aandacht aan is besteed. Ga daarbij uit van wat je nu doet:

$\begin{array}{cccc}\text { te } & \text { vol- } & \text { te } & \text { niet van } \\ \text { veel } & \text { doende } & \text { weinig } & \text { toepassing }\end{array}$

a. Vakkennis/vaktheorie

b. Vreemde talen (Engels, Duits e.d.)

c. Een brief of een stuk schrijven

d. Met cijfers werken (wiskunde, rekenen)

e. Zelfstandig werken

f. Samenwerken met collega's

g. Met mensen omgaan

h. Praktijkoriëntatie of stage

i. Omgaan met apparatuur en materialen

j. Weten hoe een bedrijf georganiseerd is

k. Leiding geven

I. Organiseren/plannen

$\mathrm{m}$. Beroepskeuze/studiekeuze

n. Leren studeren

o. Kennis van arbeidsvoorwaarden
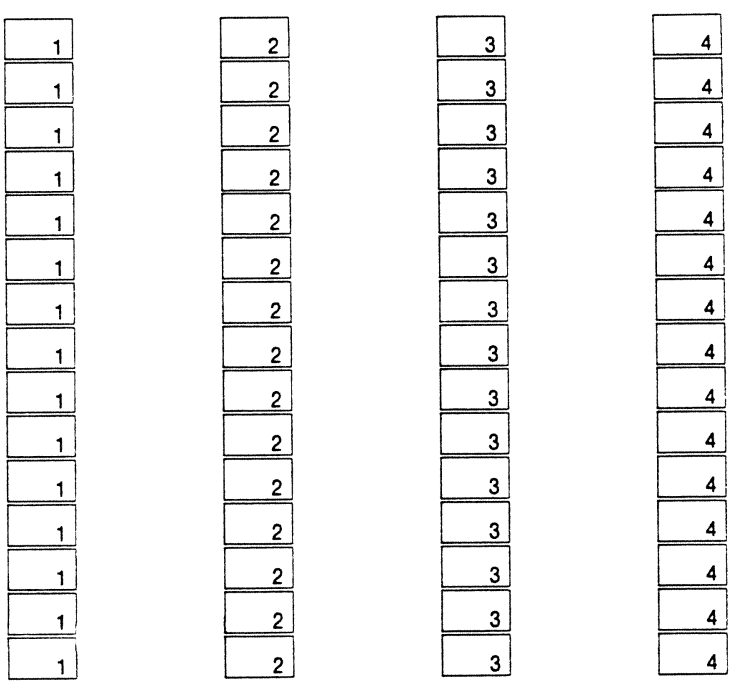

( $C A O$, ondernemingsraad, wat te doen bij ontslag e.d.)

Ruimte voor opmerkingen

Bedankt voor het invullen

Stuur de vragenlijst zo snel mogelijk op in de antwoordenvelop

(een postzegel is niet nodig) 


\section{Enkele algemene gegevens}

1. Wanneer ben je geboren?

2. Geslacht:

3. Welke taal spreek je thuis meestal met je ouders/verzorgers? maand:

jaar: 19

man

vrouw

Nederlands (ook streektaal of dialect)

Surinaams of Antilliaans

Turks of Marokkaans

Westeuropese taal (b.v. Frans, Duits)

Zuideuropese taal (b.v. Spaans, Grieks) andere taal:

4. Woonplaats:

De opleiding in het schooljaar 1987/88 (vorig jaar)

5 a. Heb je van deze opleiding vorig jaar het diploma behaald? \begin{tabular}{rr} 
nee & ja \\
alleen deelcertificaten & 2 \\
\hline
\end{tabular}

b. In welke klas ben je vorig jaar van school gegaan?

klas:

c. Heb je vorig jaar eindexamen gedaan?

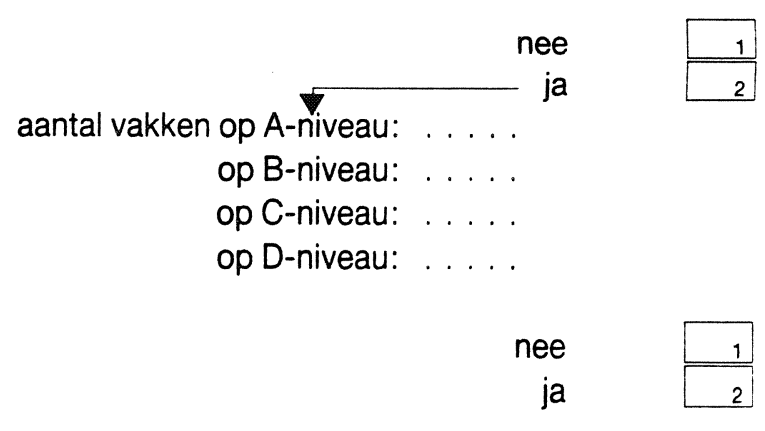

d. Heb je al eens eerder dan vorig jaar een diploma van LBO of MAVO gehaald?

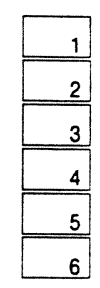


8 a. Heb je een betaalde baan gehad sinds je van school bent?

b. Zo ja, hoeveel maanden heb je in totaal gewerkt?

maanden:

Ga door met vraag 16

\section{De opleiding die je nu volgt}

Voor degenen die een full-time dagopleiding volgen:

9 a. Welke opleiding volg je op dit moment? (bijvoorbeeld: HAVO, KMBO, MTS, LTS, MEAO)

b. Welke vakrichting, afdeling of specialisatie doe je binnen deze opleiding?

(bijvoorbeeld: Bouwkunde, bestuurlijke richting)

Ga door met vraag 16

Voor degenen die een opleiding in het leerlingwezen (streekschool e.d.) of een in-service opleiding volgen:

10 a. Wat voor opleiding volg je op dit moment? (bijvoorbeeld: automonteur, installatietechniek, ziekenverzorgende, A-verpleegkundige)

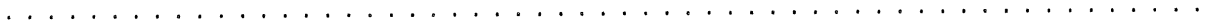

b. Naam leerlingstelsel:

(ECABO, VAM, SOM (metaal), VEV (electro), OVDB, Kappers, Horeca en dergelijke)

c. Heb je naast deze opleiding een

betaalde baan?

nee $\longrightarrow$ Ga door met vraag 16

ja

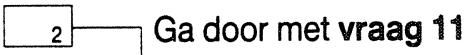

Je huidige werk en beroep

11 a. Werk je in loondienst?

nee

ja

vaste aanstelling

b. Wat voor aanstelling heb je?

tijdelijke aanstelling

werk voor uitzendbureau

c. Hoeveel uur per week werk je meestal?

minder dan 20 uur

20 tot 32 uur

meer dan 32 uur

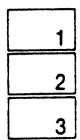


12 a. Hoe ben je aan dit werk gekomen? (één antwoord aankruisen) via het Arbeidsbureau via familie of kennissen

via een advertentie in de krant via een advertentie in een winkel e.d. via een uitzendbureau via vakantiewerk/bijbaantje door de stage/via de school zelf aan de werkgever om werk gevraagd voor mijzelf begonnen

anders: b. Hoe snel heb je werk gevonden toen je vorig jaar van school ging? meteen

na 1 - 3 maanden

na 4 - 6 maanden na meer dan 6 maanden

13 a. Hoe heet het beroep of de functie die je uitoefent?

(bijvoorbeeld: automonteur, tuinder, groepsleider, verkoopster)

b. Wat zijn je voornaamste werkzaamheden?

(bijvoorbeeld: verwarmingen installeren, veeverzorging, typen, boekhouden)

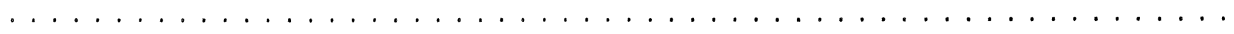

c. Op wat voor afdeling werk je?

(bijvoorbeeld: administratie, montagehal, magazijn, receptie, operatiekamer)

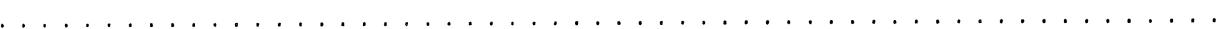

d. Geef je leiding aan ander personeel?

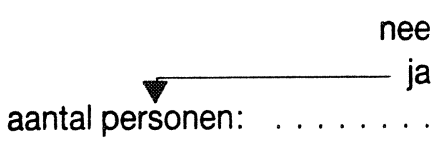

14 a. Bij wat voor bedrijf of instelling werk je?

(bijvoorbeeld: machinefabriek, constructiewerkplaats, kledingwinkel, ziekenhuis)

b. Hoeveel mensen werken er ongeveer bij het bedrijf?

minder dan 10

10 tot 50

50 tot 100

meer dan 100

weet ik niet

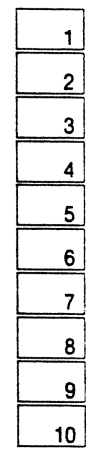

10 


\section{Werk zoeken}

16 a. Heb je de afgelopen 4 weken naar (ander) werk gezocht?

b. Zo ja, hoe heb je de afgelopen 4 weken naar werk gezocht?

(LET OP: meer antwoorden mogelijk)

via het Arbeidsbureau

via familie of kennissen

via advertenties in de krant via advertenties in winkels e.d.

via een uitzendbureau via de stage/school zelf aan een werkgever om werk gevraagd anders: . . . . . . . . . . . . . . . . . . . .

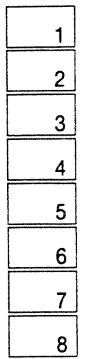

c. Sta je ingeschreven bij het Arbeidsbureau? nee

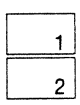

17 a. Volg je een (nog een andere) cursus, training of part-time opleiding?

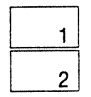

b. Welke?

\section{De opleiding achteraf bezien}

18. Hieronder noemen we een aantal zaken. Geef aan of daar in de opleiding van vorig jaar (1987/88 dus) voldoende aandacht aan is besteed.

Ga daarbij uit van wat je nu doet:

$\begin{array}{cccc}\text { te } & \text { vol- } & \text { te } & \text { niet van } \\ \text { veel } & \text { doende } & \text { weinig } & \text { toepassing }\end{array}$

a. Vakkennis/vaktheorie

b. Vreemde talen (Engels, Duits e.d.)

c. Een brief of een stuk schrijven

d. Met cijfers werken (wiskunde, rekenen)

e. Zelfstandig werken

f. Samenwerken met collega's

g. Met mensen omgaan

h. Praktijkoriëntatie of stage

i. Omgaan met apparatuur en materialen

j. Weten hoe een bedrijf georganiseerd is

k. Leiding geven

I. Organiseren/plannen

$\mathrm{m}$. Beroepskeuze/studiekeuze

n. Leren studeren

o. Kennis van arbeidsvoorwaarden (CAO, ondernemingsraad, wat te doen bij ontslag e.d.)

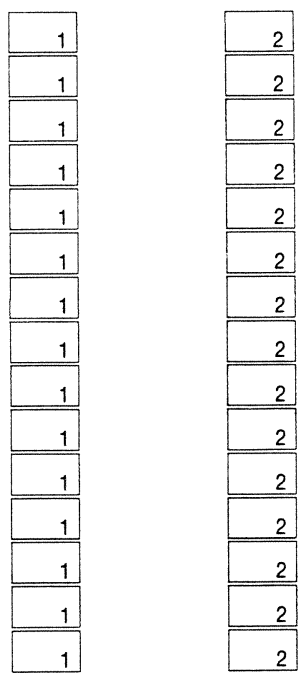

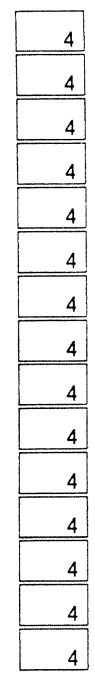

Ruimte voor opmerkingen 
Naam van bedrijf:

ingevuld door:

Onderzoek personeelssterkte metaalverwerkende bedrijven

\begin{tabular}{|c|c|c|c|c|c|c|c|c|c|c|c|c|}
\hline BEROEP & $\begin{array}{l}1 \\
\text { in dienst } \\
\text { per } \\
1 / 1 / 88^{*}\end{array}$ & $\begin{array}{l}2 \\
\text { verwachte } \\
\text { uitstroom } \\
\text { in } 1988\end{array}$ & $\begin{array}{l}3 \\
\text { verwachte } \\
\text { instroom } \\
\text { in } 1988\end{array}$ & $\begin{array}{l}4 \\
\text { soor } \\
\text { A* } \\
\text { A }\end{array}$ & nstr & $\mathrm{m} \mathrm{i}$ & D & E & $\mathbf{F}$ & G & $\begin{array}{l}5 \\
\text { aantal } \\
\text { pers.-le- } \\
\text { den } \\
\text { ouder } \\
\text { dan } 50\end{array}$ & $\begin{array}{l}6 \\
\text { geschatte } \\
\text { uitstroom } \\
\text { in } 1989\end{array}$ \\
\hline $\begin{array}{c}\text { Bankwerker } \\
\text { montage } \\
\text { machine } \\
\text { onderhouc }\end{array}$ & & & & & & & & & & & & \\
\hline Draaier & & & & & & & & & & & & \\
\hline $\begin{array}{l}\text { Elektro- } \\
\text { monteur }\end{array}$ & & & & & & & & & & & & \\
\hline Fraiser & & & & & & & & & & & & \\
\hline $\begin{array}{l}\text { Instrument- } \\
\text { maker }\end{array}$ & & & & & & & & & & & & \\
\hline $\begin{array}{l}\text { Instrumen- } \\
\text { tatie fitter }\end{array}$ & & & & & & & & & & & & \\
\hline $\begin{array}{l}\text { Isolatie plaat } \\
\text { werker }\end{array}$ & & & & & & & & & & & & \\
\hline Kotteraar & & & & & & & & & & & & \\
\hline $\begin{array}{l}\text { Lasser } \\
\text { elektrode } \\
\mathrm{mig} / \mathrm{mag} \\
\text { tig }\end{array}$ & & & & & & & & & & & & \\
\hline Pijpfitter & & & & & & & & & & & & \\
\hline IJzerwerker & & & & & & & & & & & & \\
\hline
\end{tabular}

Komende jaren verwacht: groei/stabilisatie/daling

Het totaal personeelsbestand van de gehele vestiging bedraagt:

* Kolom 1: exclusief uitzendkrachten

* Kolom 5:
A: Instroom van LTS-verlaters zonder deelname aan L.L.-stelsel
B: Instroom van LTS-verlaters met deelname aan L.L.-stelsel
C: Instroom vanuit volwassenenonderwijs, (CVV of BKE)
$D$ : Instroom van extern te werven ervaren vaklieden
E: Instroom van uitzendkrachten
F: Er vindt geen instroom plaats
G: Er wordt intern doorgeschoven 


\section{Gemeente Rotterdam}

\section{Archiefdienst}

Robert Fruinstraat 523021 XE Rotterdam

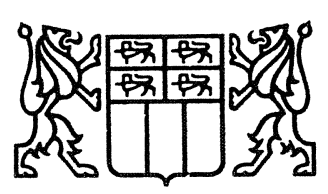

Rijksuniversiteit Limburg

Researchcentrum voor Onderwijs

en Arbeidsmarkt.

Postbus 616

6200 MD MAASTRICHT

\begin{tabular}{lll}
\hline uw kenmerk & ons kenmerk & \multicolumn{1}{c}{ telefoon } \\
& $\mathrm{Bibl} / \mathrm{CZ}$ & $(010) \mathbf{4 7 7 5 1 6 6}$ \\
uw brief van & datum & toestelnummer \\
& $23-4-1990$ & 45 \\
betreft & bijlagen & giro 161800
\end{tabular}

toezending publicatie

Door middel van een aanwinstenlijst

namen wij kennis van de vermelding van de publicatie

Naar een informatiesysteem onderwijs-arbeidsmarkt voor de haven van Rotterdam : verslag vooronderzoek / A. de Grip.

Wij zouden het bijzonder op prijs stellen wanneer wij een exemplaar van bovengenoemde publicatie voor onze archiefbibliotheek mochten ontvangen.

Bij voorbaat dank!

Hoogachtend,

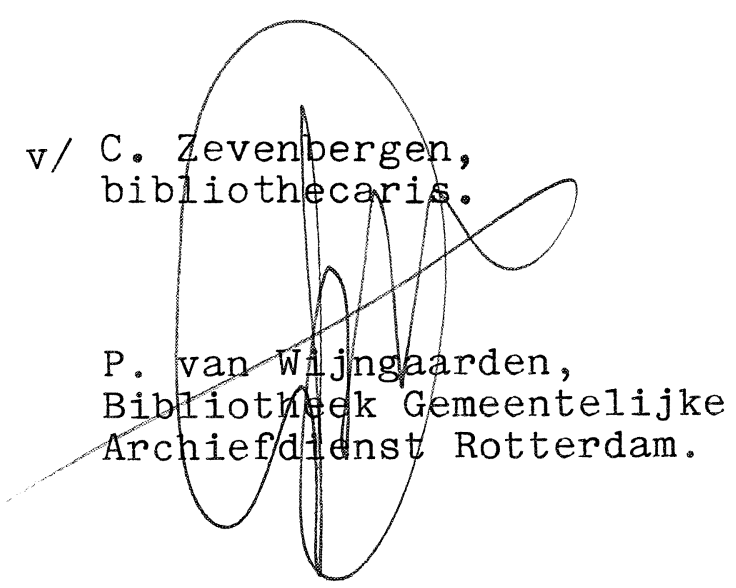

